\title{
Trypetheliaceae of Bolivia: an updated checklist with descriptions of twenty-four new species
}

\author{
Adam FLAKUS, Martin KUKWA and André APTROOT
}

\begin{abstract}
The present treatment shows that the lichen family Trypetheliaceae is an important component of lowland and montane tropical forests in Bolivia. A total of 75 species are currently recognized in Bolivia, of which 24 are new to science and a further 37 are reported for the first time from the country. The following species are described: Architrypethelium penuriixanthum Flakus \& Aptroot sp. nov. that differs from $A$. hyalinum in the lack of lichexanthone in the thallus; Astrothelium amylosporum Flakus \& Aptroot sp. nov. that differs from $A$. subdisjunctum in having 8 -spored asci and amyloid ascospores; $A$. bullatum Flakus \& Aptroot sp. nov. that differs from $A$. megaspermum in having a bullate thallus, a clear hamathecium, 8-spored asci and smaller amyloid ascospores; $A$. carrascoense Flakus, Kukwa \& Aptroot sp. nov. that differs from $A$. meristosporum in having broader ascospores without distinctly thickened median septa, an unidentified xanthone as major substance, and mostly eccentric ostioles; A. elixii Flakus \& Aptroot sp. nov. that differs from all other Astrothelium species in the presence of lichexanthone in the outer layer of thallus and pseudostromata and isohypocrellin inside the pseudostromata, and muriform ascospores; A. inspersotuberculosum Flakus \& Aptroot sp. nov. that differs from A. tuberculosum in having an inspersed hamathecium; $A$. megaeneum Flakus \& Aptroot sp. nov. that differs from $A$. croceum in having a thallus covered by parietin, and mostly fused ascomata with intermediate, fused to separated ostioles surrounded by a common ostiolar area; $A$. neodiplocarpum Flakus, Kukwa \& Aptroot sp. nov. that differs from $A$. diplocarpum in the absence of medullary pigment and in the amyloid ascospores; $A$. nigrocacuminum Flakus, Kukwa \& Aptroot sp. nov. that differs from $A$. megochroleucum in having fused, eccentric ostioles and black (UV-) tops of the pseudostromata; A. pallidoflavum Flakus \& Aptroot sp. nov. that differs from $A$. cinnamomeum in having wider ascospores; $A$. pyrenuliforme Flakus \& Aptroot sp. nov. that differs from $A$. ecuadoriensis ecuadoriense in having shorter ascospores and in the presence of pseudocyphellae; A. subscoria Flakus \& Aptroot sp. nov. that differs from $A$. scoria in having non-aggregated ascomata; A. variabile Flakus \& Aptroot sp. nov. that differs from $A$. ochroleucoides in the longer ascospores; Bathelium boliviense Flakus \& Aptroot sp. nov. that differs from B. lineare in the presence of isohypocrellin inside the pseudostromata; B. flavostiolatum Flakus \& Aptroot sp. nov. that differs from all other Bathelium species in the presence of lichexanthone near the ostioles (tops of pseudostromata UV+ yellow) and an orange (K+ carmine red) pigment inside the pseudostromata, the absence of lichexanthone in the thallus, an inspersed hamathecium, and 13-17-septate ascospores; B. inspersomastoideum Flakus \& Aptroot sp. nov. that differs from $B$. mastoideum in having an inspersed hamathecium; B. mirabile Flakus, Kukwa \& Aptroot sp. nov. that differs from other Bathelium species in the pseudostromata containing isohypocrellin inside and parietin outside; B. pruinosum Flakus, Kukwa \& Aptroot sp. nov. that differs from Astrothelium ochroleucoides in having 8-spored asci, shorter ascospores, an inspersed hamathecium, and an unidentified anthraquinone (orange pigment $\mathrm{K}+$ carmine red) inside the pseudostromata; Constrictolumina chiquitana Flakus, Kukwa \& Aptroot sp. nov. that differs from other known Constrictolumina species in having brown and 1-septate to submuriform ascospores; Dictyomeridium lueckingii Flakus \& Aptroot sp. nov. that differs from D. proponens in having smaller and less septate ascospores; Polymeridium xanthoexcentricum Flakus \& Aptroot sp. nov. that differs from $P$. alboflavescens in having mostly eccentric ostioles; Pseudopyrenula flavosuperans Flakus \& Aptroot sp. nov. that differs from $P$. superans in having a hamathecium inspersed with yellow oil globules; Trypethelium astroideum Flakus \& Aptroot sp. nov. that differs from T. subeluteriae in having $\mathrm{K}+$ carmine red pseudostromata containing parietin inside and black tops with an additional unidentified anthraquinone (rust-red pigment $\mathrm{K}+$ purple, UV-) on the outside, partly fused ostioles, and larger ascospores; and T. xanthoplatystomum Flakus \& Aptroot sp. nov. that differs from T. platystomum in the presence of lichexanthone in the thallus.
\end{abstract}

A. Flakus: Laboratory of Lichenology, W. Szafer Institute of Botany, Polish Academy of Sciences, Lubicz 46, PL-31-512 Krakow, Poland. Email: a.flakus@, botany.pl
M. Kukwa: Department of Plant Taxonomy and Nature Conservation, University of Gdańsk, Wita Stwosza 59, PL-80-308 Gdańsk, Poland.

A. Aptroot: ABL Herbarium, G. v. d. Veenstraat 107, NL-3762 XK Soest, The Netherlands. 
Key words: Architrypethelium, Astrothelium, Bathelium, biodiversity, Constrictolumina, Dictyomeridium, Dothideomycetes, lichens, Neotropics, Polymeridium, Pseudopyrenula, pyrenocarpous lichens, South America, taxonomy, Trypethelium

\section{Introduction}

Bolivia has the highest ecosystem diversity in South America (Josse et al. 2003). Consequently, we can assume that its lichen biota is very rich, and the number of species should be at least as high as in Brazil, Colombia, Peru or Venezuela (Lücking et al. 2009). Indeed, despite the extensive research carried out in this area recently, it appears that our knowledge of the lichen diversity and systematics of many taxa in Bolivia remains far from complete, and interesting discoveries are continuously being made there. Here we provide the first checklist for the family Trypetheliaceae Zenker (Dothideomycetes O. E. Erikss. \& Winka; Wijayawardene et al. 2014) in Bolivia.

The family Trypetheliaceae is most abundant in the tropics. Malme (1924) previously documented a particularly speciose biota of the family from the Caatinga vegetation in Brazil. Recent collections from Bolivia, Brazil (especially Rondônia), Guyana and Venezuela suggest that the family is speciose in primary forest in seasonally dry parts of the neotropical lowlands and humid Andean foothills (e.g., Aptroot \& Cáceres 2014, 2016; Aptroot et al. 2016; Aptroot \& Lücking 2016). Long-term lichenological fieldwork conducted by the first two authors and collaborators in Bolivia provided a good opportunity for a study of the diversity of the family in this country. The surprising number of 24 new species was discovered. These are presented below, together with a complete list of all family members found so far in Bolivia.

\section{Material and Methods}

Our study is based on material collected by the first two authors and collaborators: more than 280 specimens from 65 localities, deposited in ABL, B, KRAM, LPB, UGDA, and hb. Flakus. The morphology and anatomy were examined using a NIKON SMZ800 and a NIKON
ECLIPSE $80 i$ (DIC) microscope. Hand-cut sections and squash mounts were examined in tap water, $10 \%$ solution of potassium hydroxide $(\mathrm{K})$ or lactophenol cotton blue (LPCB). The amyloidity of lichen structures was studied using Lugol's solution (Fluka, catalogue number $62650-1 \mathrm{~L}-\mathrm{F}$ ), without (I) or with pretreatment with $\mathrm{KOH}(\mathrm{K} / \mathrm{I})$. All measurements were made on material mounted in tap water. Lichen substances were investigated by thin-layer chromatography (TLC) in solvents A, B' and C following the methods of Orange et al. (2001). Confirmation of the identified substances was achieved by running the extracts adjacent to an extract containing known substances, for example from Ochrolechia arborea (lichexanthone), Phaeographis leprieurii (isohypocrellin) and Xanthoria parietina (parietin). Details of the descriptive terminology and recent determination keys can be found in Hawksworth (1985), Aptroot (1991, 2009), Aptroot et al. (2008), Aptroot \& Cáceres (2014), and Aptroot \& Lücking (2016).

\section{The New Species}

\section{Architrypethelium penuriixanthum Flakus \& Aptroot sp. nov.}

\section{MycoBank No.: MB 812943}

Differs from Architrypethelium hyalinum Aptroot in the lack of lichexanthone in the thallus (UV-).

Type: Bolivia, Dept. Cochabamba, Prov. Carrasco, Parque Nacional Carrasco, near Sehuencas village, $17^{\circ} 30^{\prime} 12^{\prime \prime S}, 65^{\circ} 16^{\prime} 30^{\prime \prime W}, 2220 \mathrm{~m}$, Yungas cloud forest, corticolous, 21 July 2008, A. Flakus 10559, M. Kukwa $\mathbb{E}$ P. Rodriguez (LPB-holotype).

\section{(Figs 1A \& 2A)}

Thallus corticate, with corticiform layer c. $20 \mu \mathrm{m}$ thick, smooth, matt, continuous, not inducing swellings of the host bark, covering areas $\leq 5 \mathrm{~cm}$ diam., c. $0.8 \mathrm{~mm}$ thick, olivegreen, surrounded by a black prothallus.

Ascomata globose, $0.6-0.8 \mathrm{~mm}$ diam., single, immersed in the thallus, barely raised above the thallus, ascomatal verrucae hemispherical, thalline cover inside containing bark tissues. Wall fully carbonized, not differentiated into excipulum and involucrellum, $\leq c$. $70 \mu \mathrm{m}$ wide. Ostioles apical, not fused, 

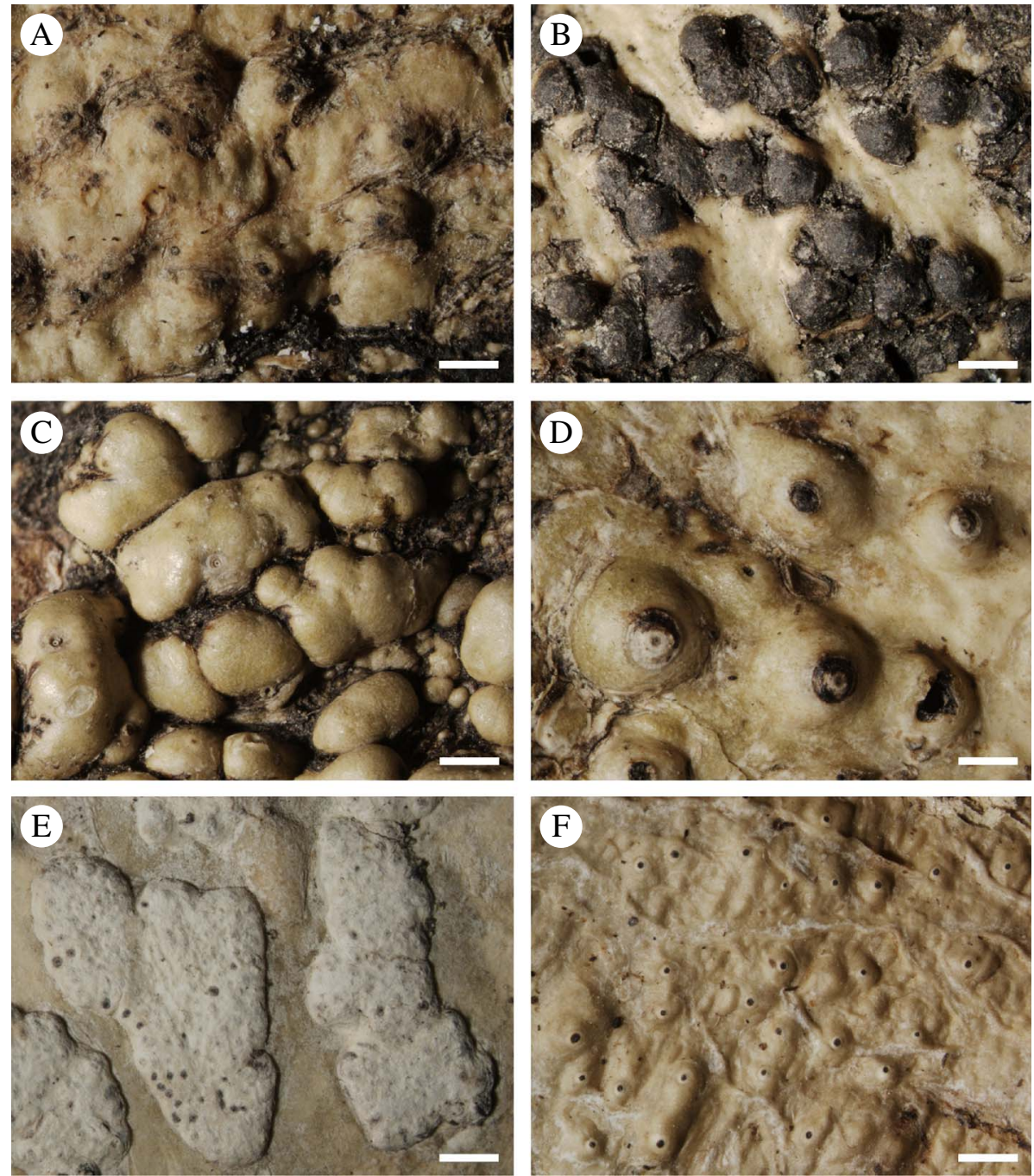

FIG. 1. Habitus of new species of Trypetheliaceae from Bolivia (holotypes). A, Architrypethelium penuriixanthum; B, Astrothelium amylosporum; C, A. bullatum; D, A. carrascoense; E, A. elixii; F, A. inspersotuberculosum. Scales $=1 \mathrm{~mm}$. In colour online.

flat to slightly convex, black. Hamathecium clear. Asci 8-spored. Ascospores hyaline, I-, 3-septate, fusiform and slightly curved, $115-185 \times 35-60 \mu \mathrm{m}$, ends pointed, constricted at the septa, lumina diamondshaped, surrounded by a gelatinous layer $\leq 15 \mu \mathrm{m}$ thick.

Pycnidia not observed.

Chemistry. Thallus surface UV-, K-, thallus medulla $\mathrm{K}-$; pseudostromata surface
UV-, inner part of pseudostromata $\mathrm{K}-$. TLC: an unknown substance (major) with $\mathrm{Rf}$ class values A6, B5, C6 detected; pale orange in daylight and grey-brown in $366 \mathrm{UV}$ after heating.

Etymology. The name refers to the lack of xanthones in the thallus.

Distribution and habitat. So far known only from Bolivia in Yungas montane cloud forest. 

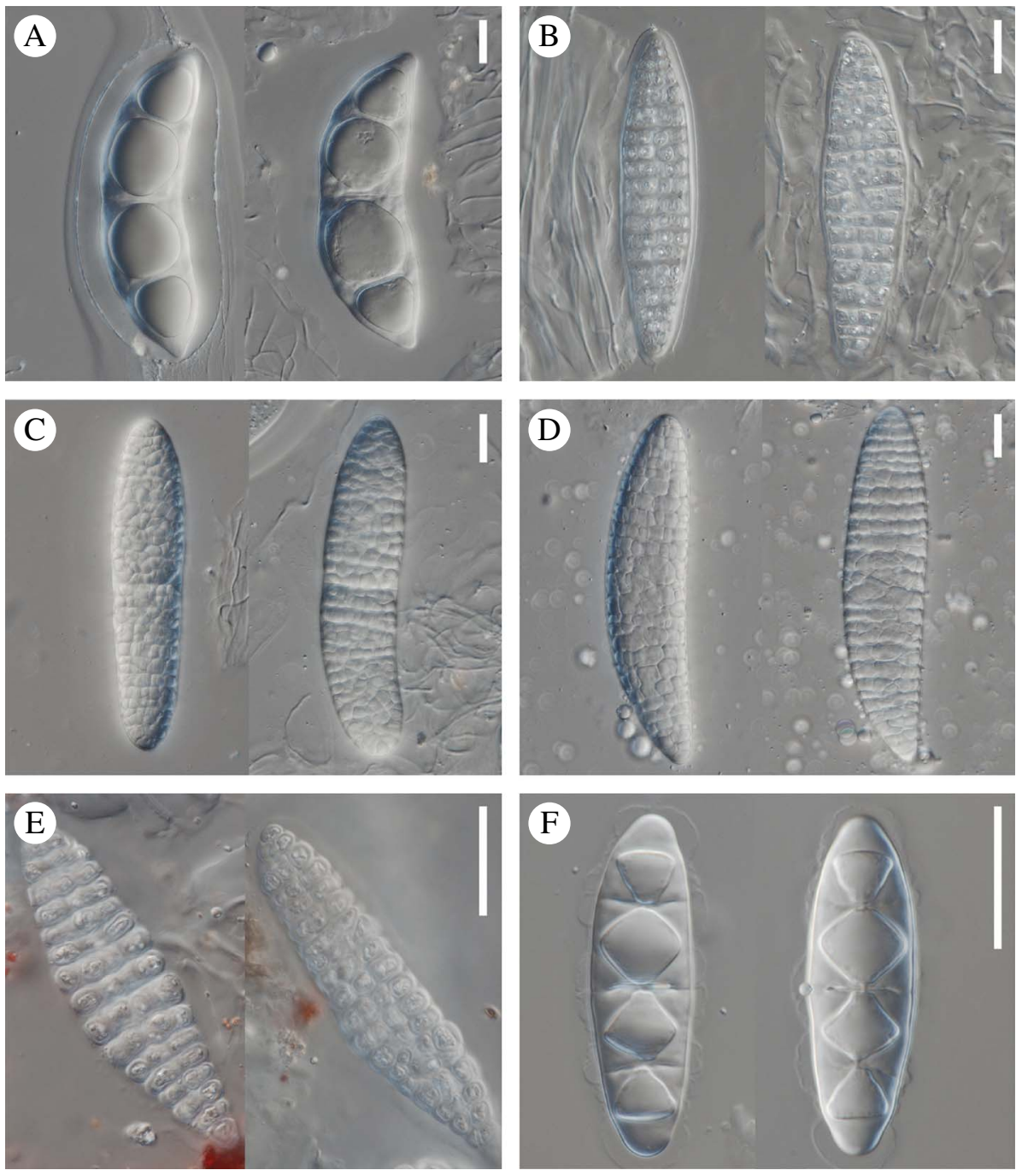

FIG. 2. Ascospores in new species of Trypetheliaceae from Bolivia (holotypes). A, Architrypethelium penuriixanthum; B, Astrothelium amylosporum; C, A. bullatum; D, A. carrascoense; E, A. elixii; F, A. inspersotuberculosum. Scales $=25 \mu \mathrm{m}$. In colour online.

Notes. Architrypethelium penuriixanthum is characterized by single ascomata immersed in the thallus, large 3-septate hyaline ascospores, a lack of xanthones in the thallus and the presence of an unknown substance as major metabolite. So far only four species of Architrypethelium are known of which only one, Architrypethelium hyalinum, has hyaline ascospores. It is, however, clearly distinct from the new species by the production of lichexanthone in the thallus (thallus UV+ yellow) (Aptroot et al. 2008; Aptroot \& Lücking 2016).

Additional specimen examined. Bolivia: Dept. La Paz: Prov. Nor Yungas, Parque Nacional y Área Natural de Manejo Integrado Cotapata, near Urpuma colony, $16^{\circ} 13^{\prime} 20^{\prime \prime} \mathrm{S}, 67^{\circ} 52^{\prime} 34^{\prime \prime} \mathrm{W}, 1989 \mathrm{~m}$, Yungas montane forest, 2010, A. Flakus 17216 \& P. Rodriguez (LPB). 


\section{Astrothelium amylosporum Flakus \& Aptroot sp. nov.}

\section{MycoBank No.: MB 812944}

Differs from Astrothelium subdisjunctum (Müll. Arg.) Aptroot \& Lücking in having 8-spored asci and amyloid ascospores.

Type: Bolivia, Dept. Santa Cruz, Prov. José Miguel de Velasco, Parque Nacional Noel Kempff Mercado, near Florida village, $14^{\circ} 35^{\prime} 50^{\prime \prime} \mathrm{S}, 61^{\circ} 50^{\prime} 46^{\prime \prime} \mathrm{W}, 220 \mathrm{~m}$, Moxos savannah with trees, corticolous, 15 December 2009, A. Flakus 15718 \& P. Rodriguez (KRAM-holotype; LPB, hb. Flakus - isotypes).

\section{(Figs 1B \& 2B)}

Thallus corticate, with corticiform layer 30-50 $\mu \mathrm{m}$ thick, smooth, somewhat shiny, continuous, not inducing swellings of the host bark, covering areas $\leq 7 \mathrm{~cm}$ diam., c. $0.15 \mathrm{~mm}$ thick, olive-green, surrounded by a black prothallus.

Pseudostromata with a surface different from the thallus, distinctly raised above the thallus with sloping sides, c. 1-3 $\times$ $1.5-4.0 \mathrm{~mm}$ and $1 \mathrm{~mm}$ high, black, inside containing bark tissue. Ascomata globose, $0.8-1.0 \mathrm{~mm}$ diam., mostly aggregated, when simple ascomatal verrucae hemispherical, or immersed in pseudostromata that are irregular in outline. Wall fully carbonized, not differentiated into excipulum and involucrellum, thicker, $\leq c .130 \mu \mathrm{m}$ wide in the upper part, and thinner, $\leq c .50 \mu \mathrm{m}$ wide, near the base. Ostioles apical, not fused, flat, black. Hamathecium clear. Asci 8-spored. Ascospores hyaline, I+ violet, densely muriform, without distinctly thickened median septa, narrowly ellipsoid, $125-170 \times 27-40 \mu \mathrm{m}$, ends rounded, lumina diamond-shaped, surrounded by a gelatinous layer $\leq 2 \mu \mathrm{m}$ thick.

Pycnidia not observed.

Chemistry. Thallus surface UV-, K-, thallus medulla $\mathrm{K}-$; pseudostromata surface $\mathrm{UV}-$, inner part of pseudostromata $\mathrm{K}-$. TLC: no secondary substances detected.

Etymology. Named after its amyloid ascospores.

Distribution and habitat. So far the species is known only from Moxos savannah in Bolivia.
Notes. Astrothelium amylosporum can be distinguished by black pseudostromata, apical and not fused ostioles, 8-spored asci with amyloid, muriform ascospores without median septa, and the absence of secondary metabolites. The most similar species, A. subdisjunctum, clearly differs by its nonamyloid ascospores and 1-2(-4)-spored asci (Aptroot et al. 2008; Aptroot \& Lücking 2016).

Additional specimen examined. Bolivia: Dept. Santa Cruz: Prov. José Miguel de Velasco, Parque Nacional Noel Kempff Mercado, near Florida village, $14^{\circ} 35^{\prime} 50^{\prime \prime} \mathrm{S}$, $61^{\circ} 50^{\prime} 46^{\prime \prime W}, 220 \mathrm{~m}$, Moxos savannah with trees, 2009, A. Flakus 15749 \& P. Rodriguez (KRAM, LPB).

\section{Astrothelium bullatum Flakus \& Aptroot sp. nov.}

MycoBank No: MB 812945

Differs from Astrothelium megaspermum (Mont.) Aptroot \& Lücking in having a bullate thallus, a clear hamathecium, 8-spored asci and smaller amyloid ascospores.

Type: Bolivia, Dept. La Paz, Prov. Nor Yungas, Parque Nacional y Área Natural de Manejo Integrado Cotapata, Santa Catalina village above Tunkini, $16^{\circ} 11^{\prime} 35^{\prime \prime} \mathrm{S}, 67^{\circ} 52^{\prime} 16^{\prime \prime} \mathrm{W}, 1700 \mathrm{~m}$, Yungas montane forest, corticolous, 22 May 2011, A. Flakus 21301 \& O. Plata (KRAM-holotype; LPB-isotype).

\section{(Figs 1C \& 2C)}

Thallus corticate, with corticiform layer 30-50 $\mu \mathrm{m}$ thick, strongly bullate, inducing swellings of the host bark, somewhat shiny, discontinuous, covering areas $\leq 8 \mathrm{~cm}$ diam., c. $2.5 \mathrm{~mm}$ thick, greyish green, without prothallus, with a thick, white medullary layer incrusted with colourless crystals not dissolving in $\mathrm{K}$.

Ascomata globose, $0.8-1.0 \mathrm{~mm}$ diam., single to aggregated, totally immersed in thallus verrucae, irregular in outline, greyish green, thalline cover without bark tissue. Wall fully carbonized, not differentiated into excipulum and involucrellum, $\leq c .90 \mu \mathrm{m}$ wide. Ostioles mostly eccentric, not fused, flat to convex, concolourous with the thallus. Hamathecium clear. Asci 8-spored. Ascospores hyaline, I+ violet, densely muriform, without 
distinctly thickened median septa, narrowly ellipsoid, $140-200 \times 30-45 \mu \mathrm{m}$, ends rounded, lumina diamond-shaped, surrounded by an $\leq 5 \mu \mathrm{m}$ thick gelatinous layer.

Pycnidia not observed.

Chemistry. Thallus surface UV-, K-, thallus medulla $\mathrm{K}-$; pseudostromata surface UV-, inner part of pseudostromata $\mathrm{K}-$. TLC: no secondary substances detected.

Etymology. The epithet refers to the strongly bullate thallus.

Distribution and habitat. So far the species is known only from the type locality in Bolivia, where it grows in Yungas montane forest.

Notes. Astrothelium bullatum is easily recognized by the strongly bullate and thick thallus, ascomata that are totally immersed in the thallus, a clear hamathecium, and 8-spored asci with small muriform, amyloid and narrowly ellipsoid ascospores. The new species has similar ascospores to $A$. megalostomum (Vain.) Aptroot \& Lücking and $A$. megaspermum. The first differs by its UV+ yellow pseudostromata, inspersed hymenium, 2-spored asci and non-amyloid ascospores, whereas the latter has comparatively wider, nonamyloid ascospores, and constantly 4-spored asci (Aptroot \& Lücking 2016).

\section{Astrothelium carrascoense Flakus, Kukwa \& Aptroot sp. nov.}

MycoBank No.: MB 812946

Differs from Astrothelium meristosporum (Mont. \& Bosch) Aptroot \& Lücking in having broader ascospores without distinctly thickened median septa, an unidentified xanthone as major substance (thallus and pseudostromata UV+ yellow in part), and mostly eccentric ostioles.

Type: Bolivia, Dept. Cochabamba, Prov. Carrasco, Parque Nacional Carrasco, near Sehuencas, $17^{\circ} 29^{\prime} 48^{\prime \prime}$, $65^{\circ} 16^{\prime} 22^{\prime \prime W}, 2250 \mathrm{~m}$, vegetation with Alnus sp. along the river within Yungas cloud forest, corticolous, 18 August 2012, A. Flakus 24647 (KRAM-holotype; LPB, hb. Flakus-isotypes).

\section{(Figs 1D \& 2D)}

Thallus corticate, with corticiform layer $\leq c$. $60 \mu \mathrm{m}$ thick, smooth to somewhat bullate, somewhat shiny, continuous, not inducing swellings of the host bark, covering areas $\leq 8 \mathrm{~cm}$ diam., c. $2 \mathrm{~mm}$ thick, greyish to yellowish green, without prothallus.

Ascomata subglobose to pyriform, 1.0$1.6 \mathrm{~mm}$ diam., single, immersed to superficial, fully covered by thallus, ascomatal verrucae hemispherical with sloping to almost vertical sides, greyish to yellowish green, bark tissue inside of the thalline cover. Wall fully carbonized, not differentiated into excipulum and involucrellum, $\leq c .100 \mu \mathrm{m}$ wide. Ostioles mostly eccentric, not fused, flat, white, and then usually surrounded by a grey spot, or black. Hamathecium inspersed with hyaline oil globules. Asci 8-spored. Ascospores hyaline, I-, densely muriform, without distinctly thickened median septa, narrowly ellipsoid, slightly curved, 150-210 $\times 40$ $50 \mu \mathrm{m}$, ends rounded, lumina diamondshaped, surrounded by a gelatinous layer $\leq 2 \mu \mathrm{m}$ thick.

Pycnidia not observed.

Chemistry. Thallus surface in part UV+ yellow, $\mathrm{K}-$, thallus medulla $\mathrm{K}-$; pseudostromata surface in part UV+ yellow, inner part of pseudostromata K-. TLC: an unidentified xanthone similar to coronatone (major) and two additional xanthones (minor) in lower Rf classes.

Etymology. The species is named after the type locality in Carrasco National Park.

Distribution and habitat. So far the species has been found only in the Yungas montane cloud forest in Carrasco National Park, Bolivia.

Notes. The characteristic features of Astrothelium carrascoense are large, single ascomata fully covered by a green thallus (sometimes with naked top), eccentric and not fused ostioles, an inspersed hamathecium, broad muriform and non-amyloid ascospores without median septa, and the presence of an unidentified xanthone as a major metabolite. Astrothelium meristosporum is closely related to the new species, but can be mainly distinguished by its narrower ascospores 
(25-40 $\mu \mathrm{m}$ wide) with distinct median septa, and apical ostioles (Aptroot \& Lücking 2016).

Additional specimens examined. Bolivia: Dept. Cochabamba: Prov. Carrasco, Parque Nacional Carrasco near Sehuencas village, $17^{\circ} 30^{\prime} 12^{\prime \prime} \mathrm{S}, 65^{\circ} 16^{\prime} 30^{\prime \prime} \mathrm{W}, 2220 \mathrm{~m}$, Yungas cloud forest, corticolous, 2008, A. Flakus 10537 \& P. Rodriguez (ABL, KRAM, LPB), M. Kukwa 6452, 6544 (LPB, UGDA); near Sehuencas village close to Río Lopez Mendoza, $17^{\circ} 30^{\prime} 26^{\prime \prime} \mathrm{S}, 65^{\circ} 16^{\prime} 55^{\prime \prime W}$, $2226 \mathrm{~m}$, Yungas cloud forest, corticolous, 2008, A. Flakus 10684, M. Kukwa \& P. Rodriguez (ABL, KRAM, LPB).

\section{Astrothelium elixii Flakus \& Aptroot sp. nov.}

MycoBank No.: MB 812947

Differs from all other Astrothelium species by the presence of lichexanthone in the outer layer of thallus and pseudostromata (UV + yellow) and isohypocrellin (red-purple, $\mathrm{K}+$ green pigment) inside the pseudostromata, and muriform ascospores.

Type: Bolivia, Dept. Beni, Prov. Yacuma, RB Estación Biológica del Beni, near biological station, $14^{\circ} 51^{\prime} 07^{\prime \prime} \mathrm{S}, 66^{\circ} 20^{\prime} 23^{\prime \prime} \mathrm{W}, 175 \mathrm{~m}$, island of lowland Amazon forest among Moxos savannah, corticolous, 6 November 2010, A. Flakus 17897 \& F. Saavedra (KRAM-holotype; LPB-isotype).

\section{(Figs 1E \& 2E)}

Thallus corticate, with corticiform layer $\leq c$. $30 \mu \mathrm{m}$ thick, smooth, pruinose, continuous, not inducing swellings of the host bark, covering areas $\leq 6 \mathrm{~cm}$ diam., c. $0.2 \mathrm{~mm}$ thick, greyish green, not surrounded by prothallus.

Pseudostromata with a surface different from the thallus, distinctly raised above the thallus, irregular in outline with almost vertical sides, $2-3 \times 4-9 \mathrm{~mm}$ wide and $0.6 \mathrm{~mm}$ high, white, strongly pruinose, inside with granular red-purple crystals (K+green), without bark tissue. Ascomata pyriform, 0.3-0.5 mm diam., aggregated, fully immersed in pseudostromata, with ascomatal base often immersed in the bark. Wall fully carbonized, not differentiated into excipulum and involucrellum, $\leq c .30 \mu \mathrm{m}$ wide. Ostioles apical, not fused, flat, black, punctiform. Hamathecium clear. Asci with 4-8 ascospores. Ascospores hyaline, I-, densely muriform, without distinctly thickened median septa, narrowly ellipsoid to fusiform, $70-150 \times 17-32 \mu \mathrm{m}$, ends pointed, lumina diamond-shaped, rarely surrounded by a gelatinous layer $\leq 2 \mu \mathrm{m}$ thick.

Pycnidia not observed.

Chemistry. Thallus surface UV+ yellow, $\mathrm{K}+$ yellowish, thallus medulla $\mathrm{K}-$; pseudostromata surface UV+ yellow, granular red-purple pigment in inner part of pseudostromata $\mathrm{K}+$ green. TLC: lichexanthone (major) and isohypocrellin (major) with related substances detected.

Etymology. The new species is named in honour of our friend Professor John Elix (Canberra), the prominent Australian lichenologist, for his magnificent contribution to the knowledge of lichen chemistry.

Distribution and habitat. So far the species is known only from the type locality in Bolivia, where it grows in islands of lowland Amazon forest in Moxos savannah.

Notes. Astrothelium elixii is characterized by large, strongly pruinose white pseudostromata, the presence of lichexanthone in the outer layer of thallus and pseudostromata and isohypocrellin inside the pseudostromata, and the narrowly ellipsoid and muriform ascospores. There are only two species of Astrothelium known to produce isohypocrellin (red-purple, $\mathrm{K}+$ green pigment) in pseudostromata, $A$. purpurascens (Müll. Arg.) Aptroot \& Lücking and $A$. sanguinarium (Malme) Aptroot \& Lücking. However, both clearly differ in pseudostroma morphology and the absence of lichexanthone (thallus UV-) (Aptroot \& Lücking 2016).

\section{Astrothelium inspersotuberculosum Flakus \& Aptroot sp. nov.}

\section{MycoBank No.: MB 812948}

Differs from Astrothelium tuberculosum (Vain.) Aptroot \& Lücking in having an inspersed hamathecium.

Type: Bolivia, Dept. Santa Cruz, Prov. José Miguel de Velasco, Hacienda Chirapa near Florida village, $14^{\circ} 33^{\prime} 22^{\prime \prime} \mathrm{S}, 61^{\circ} 16^{\prime} 03^{\prime \prime} \mathrm{W}, 200 \mathrm{~m}$, lowland Amazon forest, corticolous, 16 December 2009, A. Flakus 
16218 \& P. Rodriguez (KRAM-holotype; LPB, hb. Flakus-isotypes).

\section{(Figs $1 F \& 2 F$ )}

Thallus corticate, with corticiform layer 30-50 $\mu \mathrm{m}$ thick, smooth to somewhat bullate, not inducing swellings of the host bark, somewhat shiny, continuous, covering areas $\leq 7 \mathrm{~cm}$ diam., c. $0.4 \mathrm{~mm}$ thick, green, containing large clusters of crystals not dissolving in $\mathrm{K}$, not surrounded by prothallus.

Ascomata pyriform, $0.4-0.5 \mathrm{~mm}$ diam., single to aggregated, immersed in the thallus with the base immersed in the bark, ascomatal verrucae hemispherical or irregular in outline with sloping sides, green, thalline cover inside with a white crystal cluster and bark tissue. Wall fully carbonized, not differentiated into excipulum and involucrellum, $\leq c .30 \mu \mathrm{m}$ wide, surrounded by a hyaline to pale brown outer layer 15-60 $\mu \mathrm{m}$ wide. Ostioles apical, not fused, flat, black, surrounded by a white spot. Hamathecium inspersed with hyaline oil globules. Asci 8-spored. Ascospores hyaline, I-, 3-septate, narrowly ellipsoid, 45-62 $\times$ $15-18 \mu \mathrm{m}$, ends rounded, lumina diamondshaped, not surrounded by a gelatinous layer when mature.

Pycnidia not observed.

Chemistry. Thallus surface UV-, K-, thallus medulla $\mathrm{K}-$; pseudostromata surface UV-, inner part of pseudostromata $\mathrm{K}-$. TLC: no secondary substances detected.

Etymology. The specific epithet refers to the presence of an inspersed hamathecium and the similarity to $A$. tuberculosum.

Distribution and habitat. So far the species has been found in Bolivia in lowland Amazon forest.

Notes. Astrothelium inspersotuberculosum is characterized by small, single to aggregated ascomata covered by the thallus, black apical and not fused ostioles surrounded by a white spot, a strongly inspersed hamathecium and large, 3-septate non-amyloid ascopores. The new species is reminiscent of $A$. tuberculosum, which can be distinguished by its clear hymenium. Inspersion of the hamathecium by oil globules was recently considered an important taxonomical character in Trypetheliaceae (Aptroot et al. 2008; Aptroot \& Lücking 2016).

Additional specimen examined. Bolivia: Dept. Santa Cruz: Prov. José Miguel de Velasco, sendero de goma near Florida village, $14^{\circ} 37^{\prime} 48^{\prime \prime S}, 61^{\circ} 12^{\prime} 02^{\prime \prime W}, 170 \mathrm{~m}$, lowland Amazon secondary forest, corticolous, 2009, A. Flakus 16096 \& P. Rodriguez (LPB).

\section{Astrothelium megaeneum Flakus \& Aptroot sp. nov.}

\section{MycoBank No.: MB 812949}

Differs from Astrothelium croceum Malme in having a thallus covered by an orange pigment (parietin), and mostly fused ascomata with intermediate, fused to separated ostioles surrounded by a common ostiolar area.

Type: Bolivia, Dept. Santa Cruz, Prov. José Miguel de Velasco, Parque Nacional Noel Kempff Mercado, Savannah de los Fierros near Florida village, 14³6'11"S, $61^{\circ} 52$ '24"W, $205 \mathrm{~m}$, Moxos savannah, corticolous, 15 December 2009, A. Flakus 15618 \& P. Rodriguez (KRAM-holotype; LPB, hb. Flakus - isotypes).

\section{(Figs 3A \& 4A)}

Thallus corticate, with corticiform layer c. $20 \mu \mathrm{m}$ thick, smooth, matt, continuous, not inducing swellings of the host bark, covering areas $\leq 10 \mathrm{~cm}$ diam., c. $0.5 \mathrm{~mm}$ thick, orange, not surrounded by a black prothallus.

Ascomata pyriform, $0.3-0.7 \mathrm{~mm}$ diam., single or 2-5 fused together, mostly aggregated, immersed in the thallus with base often immersed in the bark, ascomatal verrucae irregular in outline and with sloping sides, orange, thalline cover not containing bark tissue. Wall fully but not uniformly carbonized, composed of several layers, not differentiated into excipulum and involucrellum, $\leq c .50 \mu \mathrm{m}$ wide (in upper part sometimes $\leq c .130 \mu \mathrm{m})$. Ostioles apical, fused to separated, when separated then 2-5 aggregated and surrounded by a common ostiolar area, black, surrounded by a greyish black, flat spot. Hamathecium clear. Asci 8-spored. Ascospores hyaline, 3-septate, narrowly ellipsoid, 26-35 × 11-12 $\mu \mathrm{m}$, ends rounded, lumina diamond-shaped, surrounded by a gelatinous layer $\leq 3 \mu \mathrm{m}$ thick. 

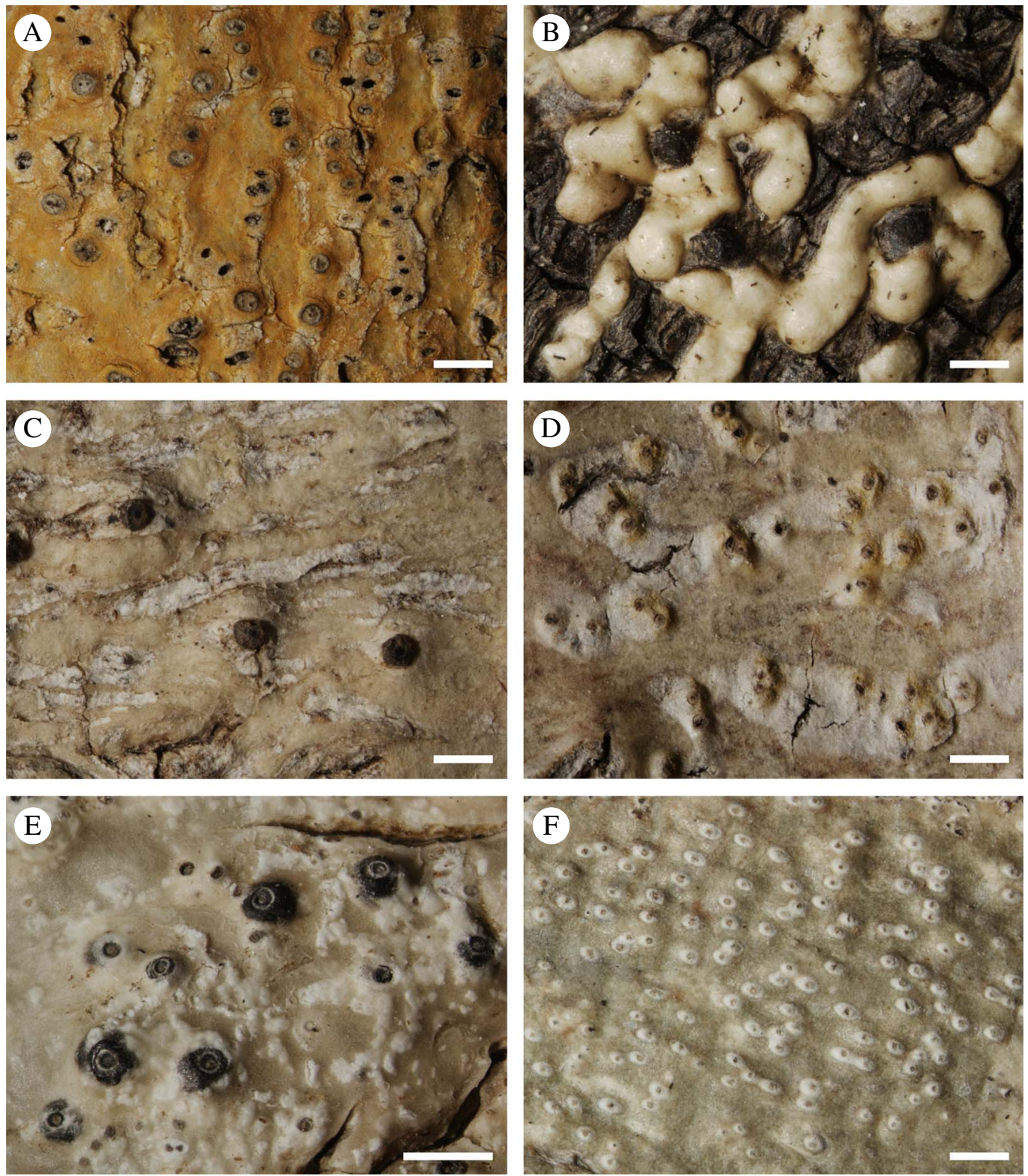

FIG. 3. Habitus of new species of Trypetheliaceae from Bolivia (holotypes). A, Astrothelium megaeneum; $\mathrm{B}, A$. neodiplocarpum; C, $A$. nigrocacuminum; D, A. pallidoflavum; E, A. pyrenuliforme; $\mathrm{F}, A$. subscoria. Scales $=1 \mathrm{~mm}$. In colour online.

Pycnidia not observed.

Chemistry. Thallus surface UV+ orange, $\mathrm{K}+$ purple, thallus medulla $\mathrm{K}-$; pseudostromata surface UV+ orange, inner part of pseudostromata $\mathrm{K}-$. TLC: parietin (major) detected.

Etymology. The specific epithet refers to the large ascomata and ascospores, and the 

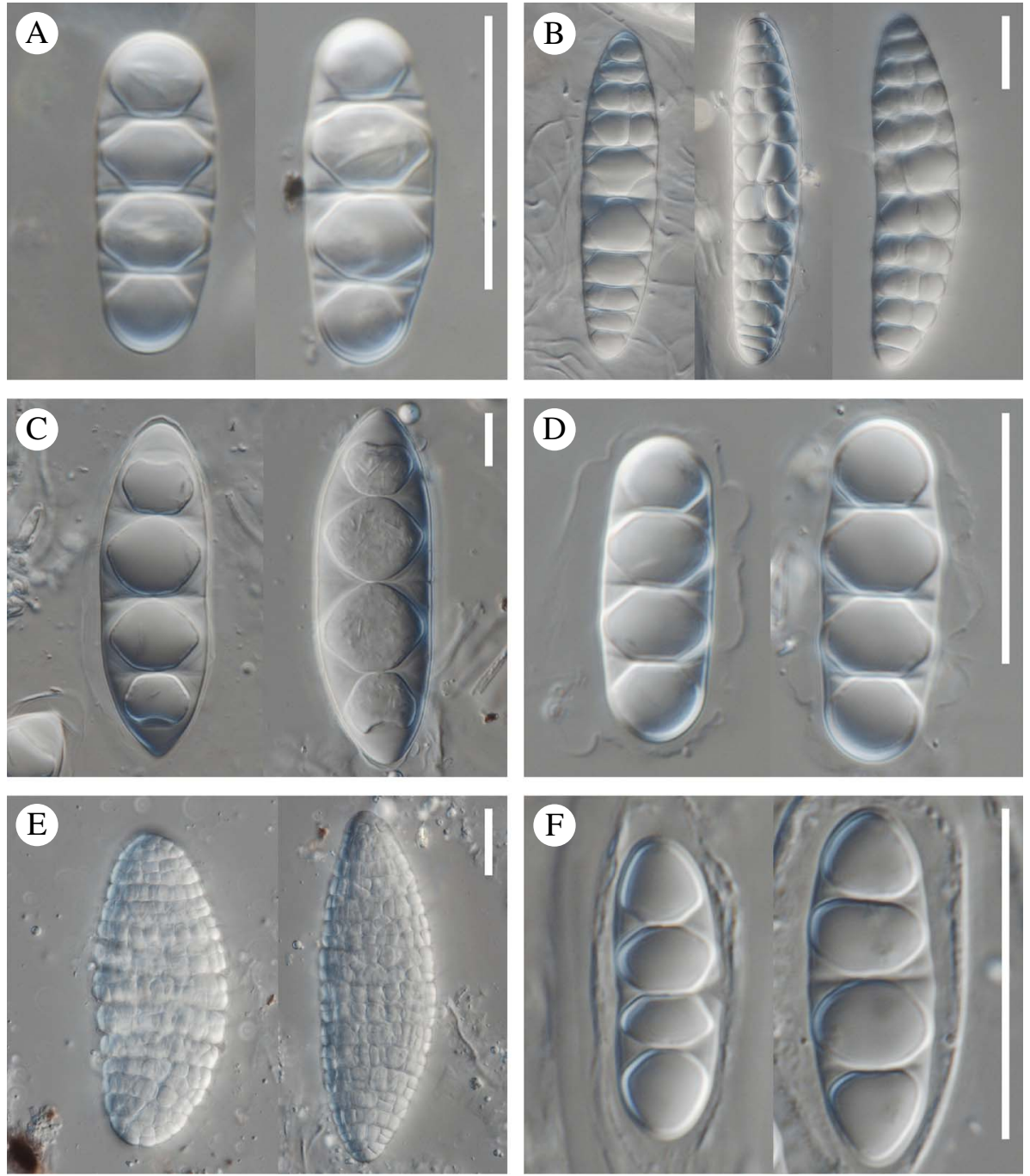

FIG. 4. Ascospores in new species of Trypetheliaceae from Bolivia (holotypes): A, Astrothelium megaeneum; $\mathrm{B}$, A. neodiplocarpum; C, A. nigrocacuminum; D, A. pallidoflavum; E, A. pyrenuliforme; F, A. subscoria. Scales: $\mathrm{A}, \mathrm{B}, \mathrm{D}-\mathrm{F}=25 \mu \mathrm{m} ; \mathrm{C}=10 \mu \mathrm{m}$. In colour online.

morphological similarity to $A$. aeneum (Eschw.) Aptroot \& Lücking.

Distribution and habitat. So far known only from the type locality in Bolivia, where it grows in lowland Moxos savannah.

Notes. Astrothelium megaeneum can be easily distinguished by its orange-pigmented thallus, fused ascomata with intermediate, fused to separated ostioles which are surrounded by a common ostiolar area, and large 3-septate ascospores. It is most similar to $A$. aeneum and $A$. croceum; however the former differs by its shorter ascospores $(20-27 \times 7-10 \mu \mathrm{m})$ and smaller ascomata, and the latter by its yellow-pigmented thallus (Aptroot et al. 2008; Aptroot \& Lücking 2016). 


\section{Astrothelium neodiplocarpum Flakus, Kukwa \& Aptroot sp. nov.}

MycoBank No.: MB 812950

Differs from Astrothelium diplocarpum Nyl. by the absence of a medullary pigment and in the amyloid ascospores (I+ violet).

Type: Bolivia, Dept. La Paz, Prov. Nor Yungas, Parque Nacional y Área Natural de Manejo Integrado Cotapata, Santa Catalina village above Tunkini, $16^{\circ} 11^{\prime} 35^{\prime \prime S}, 67^{\circ} 52^{\prime} 16^{\prime \prime} \mathrm{W}, 1700 \mathrm{~m}$, Yungas montane forest, corticolous, 22 May 2011, A. Flakus 21336 \& O. Plata (KRAM-holotype; LPB-isotype).

\section{(Figs 3B \& 4B)}

Thallus corticate, with corticiform layer c. $20-30 \mu \mathrm{m}$ thick, smooth to somewhat bullate, somewhat shiny, discontinuous, inducing swellings of the host bark, covering areas $\leq 9 \mathrm{~cm}$ diam., c. $0.8 \mathrm{~mm}$ thick, olive-green, not surrounded by a black prothallus, with a thick, white medullary layer incrusted with colourless crystal clusters not dissolving in $\mathrm{K}$.

Ascomata pyriform, 0.5-0.8 mm diam., mostly 2-4 aggregated, immersed in pseudostromata with a surface usually covered by thallus, ascomatal verrucae slightly raised above the thallus, hemispherical to irregular in outline, with sloping sides, $\leq c .2 \mathrm{~mm}$ diam. and $1.4 \mathrm{~mm}$ high, black, inside without pigments, thalline cover containing clusters of crystals and bark tissue. Wall fully carbonized, not differentiated into excipulum and involucrellum, $\leq c . \quad 150 \mu \mathrm{m}$ wide. Ostioles eccentric, fused, convex, black. Hamathecium clear. Asci 8-spored. Ascospores hyaline, I+ violet, 9-13-septate to submuriform (with additional 1-2 longitudinal septa), fusiform, 95-130 × 18-30 $\mu \mathrm{m}$, ends rounded, lumina diamond-shaped, not surrounded by a gelatinous layer.

Pycnidia not observed.

Chemistry. Thallus surface UV-, K-, thallus medulla $\mathrm{K}-$; pseudostromata surface UV-, inner part of pseudostromata $\mathrm{K}-$. TLC: no secondary substances detected.

Etymology. The name refers to the similarity with $A$. diplocarpum.
Distribution and habitat. So far the species is known only from Yungas montane cloud forests in Bolivia.

Notes. Astrothelium neodiplocarpum is characterized by pseudostromata with a few immersed ascomata, a surface usually covered by thallus, an absence of pigments, eccentric and fused ostioles, and 9-13-septate to submuriform, fusiform and amyloid ascospores. The new species is reminiscent of A. diplocarpum, which differs in its orange $(\mathrm{K}+\mathrm{red})$ medullary pigment and nonamyloid ascospores. However, Astrothelium neodiplocarpum could also be confused with A. effusum (Aptroot \& Sipman) Aptroot \& Lücking, $A$. purpurascens and $A$. sanguinarium . The first differs in having a densely inspersed hamathecium and non-amyloid ascospores, and the two further species by the presence of isohypocrellin (red-purple, $\mathrm{K}+$ green pigment) (Aptroot et al. 2008; Aptroot \& Lücking 2016).

Additional specimens examined. Bolivia: Dept. La Paz: Prov. Larecaja, near Achiquiri village, $18 \mathrm{~km}$ from Mapiri on the road to Apolo, $15^{\circ} 13^{\prime} 31^{\prime \prime} \mathrm{S}, 68^{\circ}$ 13'49"W, $1071 \mathrm{~m}$, secondary sub-Andean Amazon forest, 2011, A. Flakus 20657 \& O. Plata (LPB). Dept. Cochabamba: Prov. Carrasco, Parque Nacional Carrasco, near Phaqcha, $20 \mathrm{~km}$ from Monte Punku village, $17^{\circ} 27^{\prime} 13^{\prime \prime} \mathrm{S}, 65^{\circ} 16^{\prime} 44^{\prime \prime} \mathrm{W}, 2850 \mathrm{~m}$, Yungas cloud forest, close to the river, corticolous, 2008, M. Kukwa 6173 (LPB, UGDA).

\section{Astrothelium nigrocacuminum Flakus, Kukwa \& Aptroot sp. nov.}

\section{MycoBank No.: MB 812951}

Differs from Astrothelium megochroleucum Aptroot \& Lücking in having fused, eccentric ostioles and black (UV-) tops of the pseudostromata.

Type: Bolivia, Dept. La Paz, Prov. Franz Tamayo, between Apolo and Mapiri villages, $15^{\circ} 01^{\prime} 50^{\prime \prime} \mathrm{S}$, $68^{\circ} 18^{\prime} 33^{\prime \prime} \mathrm{W}, 1120 \mathrm{~m}$, sub-Andean Amazon forest, corticolous, 23 November 2011, M. Kukwa 10326 (LPB-holotype).

\section{(Figs 3C \& 4C)}

Thallus corticate, with corticiform layer c. $20 \mu \mathrm{m}$ thick, smooth, somewhat shiny to matt, continuous, not inducing swellings of 
the host bark, covering areas $\leq 5 \mathrm{~cm}$ diam., c. $0.2 \mathrm{~mm}$ thick, greyish green, not surrounded by a black prothallus.

Pseudostromata barely raised above the thallus, irregular in outline to hemispherical with sloping sides with a surface covered by thallus, $\leq c .1 .6 \mathrm{~mm}$ diam. and $1.2 \mathrm{~mm}$ high, black, thalline cover inside without pigments and bark tissue. Ascomata pyriform, $0.3-0.6 \mathrm{~mm}$ diam., mostly aggregated with 2-4 immersed in pseudostromata (with bases often deeply immersed in the bark). Wall fully and strongly carbonized, not differentiated into excipulum and involucrellum, $\leq c$. $80 \mu \mathrm{m}$ wide. Ostioles eccentric fused, convex, black; combined ostioles apical. Hamathecium clear. Asci 8-spored. Ascospores hyaline, I-, 3-septate, fusiform, 60-68 $\times 17-22 \mu \mathrm{m}$, ends rounded, lumina diamond-shaped, not surrounded by a gelatinous layer.

Pycnidia not observed.

Chemistry. Thallus surface UV+ yellow, $\mathrm{K}-$, thallus medulla $\mathrm{K}-$; pseudostromata surface UV+ yellow, pseudostromata top $\mathrm{UV}-$, inner parts of pseudostromata $\mathrm{K}-$. TLC: an unidentified xanthone similar to coronatone (major) detected.

Etymology. The name refers to the black tops of the ascomata protruding from the thallus cover.

Distribution and habitat. So far the species is known only from the type locality in Bolivia. It was found in sub-Andean Amazon forest.

Notes. Astrothelium nigrocacuminum is characterized by pseudostromata barely raised above the thallus surface, with the surface covered by thallus except the characteristic black tops of ascomata, by fused and eccentric ostioles, a clear hamathecium, and large non-amyloid 3-septate ascospores. Astrothelium megochroleucum is the most similar, but can be distinguished by its apical ostioles and UV+ yellow stroma (Aptroot \& Lücking 2016).

\section{Astrothelium pallidoflavum Flakus \& Aptroot sp. nov.}

MycoBank No.: MB 812952

Differs from Astrothelium cinnamomeum (Eschw.) Müll. Arg. in having wider ascospores.

Type: Bolivia, Dept. Santa Cruz, Prov. José Miguel de Velasco, Parque Nacional Noel Kempff Mercado, near Florida village, $14^{\circ} 35^{\prime} 50^{\prime \prime} \mathrm{S}, 61^{\circ} 50^{\prime} 46^{\prime \prime} \mathrm{W}, 220 \mathrm{~m}$, Moxos savannah with trees, corticolous, 15 December 2009, A. Flakus 15738 \& P. Rodriguez (KRAM-holotype; LPB-isotype).

\section{(Figs 3D \& 4D)}

Thallus corticate, with corticiform layer c. $15 \mu \mathrm{m}$ thick, smooth, somewhat shiny, continuous, not inducing swellings of the host bark, covering areas $\leq 8 \mathrm{~cm}$ diam., c. $0 \cdot 1 \mathrm{~mm}$ thick, greyish green, not surrounded by a black prothallus.

Pseudostromata with a surface colour different from the thallus, barely raised above the thallus level, irregular in outline with sloping sides, $1.5-4.0 \times 0.5-1.5 \mathrm{~mm}$ diam. and $0.4 \mathrm{~mm}$ high, white to yellow, inside without a coloured layer and bark tissues. Ascomata globose, $0.2-0.3 \mathrm{~mm}$ diam., simple or 2-3 with fused ostioles, aggregated and immersed in inconspicuous pseudostromata, base often immersed in the bark. Wall fully but not uniformly carbonized, composed of several layers, not differentiated into excipulum and involucrellum, incrusted by crystals, $\leq c$. $60 \mu \mathrm{m}$ wide. Ostioles apical to eccentric, mostly fused, flat, black, surrounded by a greyish spot. Hamathecium clear. Asci 8-spored. Ascospores hyaline, 3-septate, narrowly ellipsoid, $27-30 \times 10-12 \mu \mathrm{m}$, ends rounded, lumina diamond-shaped, surrounded by a gelatinous layer $\leq 2 \mu \mathrm{m}$ thick.

Pycnidia not observed.

Chemistry. Thallus surface UV-, K-, thallus medulla $\mathrm{K}-$; pseudostromata surface $\mathrm{UV}+$ orange, $\mathrm{K}+$ purple, inner part of pseudostromata $\mathrm{K}-$. TLC: parietin (minor) detected.

Etymology. The species is named after the pale yellow colour of the pseudostromata. 
Distribution and habitat. So far known only from the type locality in Bolivia, where it grows in Moxos savannah.

Notes. The characters distinguishing A. pallidoflavum from other species are small, simple or 2-3 ascomata immersed in inconspicuous pseudostromata with a white to yellow (containing parietin) surface, mostly fused apical to eccentric ostioles, a clear hamathecium and small 3-septate ascospores. Astrothelium pallidoflavum belongs to a group of species characterized by pseudostroma covered by a yellow to orange pigment $(\mathrm{K}+$ purple, $\mathrm{UV}+\mathrm{red})$. The most similar species are $A$. cinnamomeum, $A$. macrocarpum Kremp. and $A$. versicolor Müll. Arg. The first one differs by its pseudostromata morphology and comparatively smaller ascospores, and the two further species can be easily distinguished by the presence of lichexanthone (Aptroot et al. 2008; Aptroot \& Lücking 2016).

\section{Astrothelium pyrenuliforme Flakus \& Aptroot sp. nov.}

$$
\text { MycoBank No.: MB } 812953
$$

Differs from Astrothelium ecuadoriense Aptroot \& Lücking in the shorter ascospores and presence of pseudocyphellae.

Type: Bolivia, Dept. Santa Cruz, Prov. Cordillera, Parque Nacional y Área Natural de Manejo Integrado Kaa-Iya del Gran Chaco, park guard's station near Peto Blanco, 18 $56^{\circ} 26^{\prime \prime S}, 60^{\circ} 22^{\prime} 39^{\prime \prime} \mathrm{W}, 340 \mathrm{~m}$, Chiquitano forest, corticolous, 5 December 2011, A. Flakus 23568 (KRAM-holotype; ABL, LPB - isotypes).

\section{(Figs 3E \& 4E)}

Thallus corticate, with corticiform layer $\leq c .90 \mu \mathrm{m}$ thick, smooth, somewhat shiny, continuous, not inducing swellings of the host bark, covering areas $\leq 9 \mathrm{~cm}$ diam., c. $0.4 \mathrm{~mm}$ thick, grey-green, with small to irregular white verrucae due to the presence of crystals (calcium oxalate) below cortical layer, not surrounded by a black prothallus; pseudocortex layer covering verrucae usually breaking and forming pseudocyphellae.

Ascomata globose, $0.4-0.8 \mathrm{~mm}$ diam., mostly single, immersed in the thallus to half exposed, ascomatal verrucae barely to distinctly raised above the thallus, hemispherical with sloping sides, black, inside without a coloured layer, thalline cover not containing bark tissue, but ascomatal base often immersed in the bark. Wall fully carbonized, not differentiated into excipulum and involucrellum, $\leq c .90 \mu \mathrm{m}$ wide, thicker in the upper part $(\leq 120 \mu \mathrm{m})$ and much thinner at the base $(\leq 30 \mu \mathrm{m})$. Ostioles eccentric, not fused, flat, black, sometimes surrounded by a white spot. Hamathecium inspersed with hyaline oil globules. Asci with (1)-2 ascospores. Ascospores hyaline, I-, densely muriform, without distinctly thickened median septa, broadly ellipsoid to fusiform, 86-135 ×27-55 $\mu \mathrm{m}$, ends rounded, lumina diamond-shaped, not surrounded by a gelatinous layer.

Pycnidia not observed.

Chemistry. Thallus surface $\mathrm{UV}-, \mathrm{K}-$, thallus medulla $\mathrm{K}-$; pseudostromata surface $\mathrm{UV}-$, inner part of pseudostromata $\mathrm{K}-$. TLC: undetermined xanthone similar to lichexanthone (trace) detected.

Etymology. The specific epithet refers to the strong external resemblance of the new species to the genus Pyrenula.

Distribution and habitat. So far known only from the type locality, where it grows in lowland dry Chiquitano forest.

Notes. Astrothelium pyrenuliforme is characterized by a corticate, somewhat shiny thallus with small to irregular white verrucae, which usually breaks into pseudocyphellae, mostly single ascomata, immersed in the thallus to half exposed, with eccentric and not fused ostioles, and by an inspersed hymenium and asci with (1-) 2 muriform, broadly ellipsoid, non-amyloid ascospores. Astrothelium pyrenuliforme is most closely related to $A$. ecuadoriense. Both species have very similar muriform ascospores, 8-spored asci and an inspersed hamathecium. However, in the latter the ascospores are larger and the thallus never develops pseudocyphellae (Aptroot \& Lücking 2016). 


\section{Astrothelium subscoria Flakus \& Aptroot sp. nov.}

MycoBank No.: MB 812954

Differs from Astrothelium scoria (Fée) Aptroot \& Lücking in having non-aggregated ascomata.

Type: Bolivia, Dept. Beni, Prov. Itenez, Puerto Feliz colony by Río Blanco, $13^{\circ} 09^{\prime} 23^{\prime \prime S}, 63^{\circ} 43^{\prime} 24^{\prime \prime W}, 137 \mathrm{~m}$, lowland Amazon forest, corticolous, 16 August 2008, A. Flakus 12118 \& P. Rodriguez (LPB-holotype).

\section{(Figs 3F \& 4F)}

Thallus corticate, with corticiform layer $\leq c .30 \mu \mathrm{m}$ thick, smooth, somewhat shiny, continuous, not inducing swellings of the host bark, covering areas $\leq 3 \mathrm{~cm}$ diam., c. $0.3 \mathrm{~mm}$ thick, greyish green, surrounded by a black prothallus.

Ascomata subglobose, 0.2-0.4 mm diam., single, immersed in the thallus, ascomatal verrucae with a surface different from the thallus, not distinctly raised above the thallus, hemispherical, with sloping sides, white, inside without a coloured layer, thalline cover without bark tissues, but ascomata often immersed in the bark. Wall fully but not strongly carbonized, not differentiated into excipulum and involucrellum, $\leq c .30 \mu \mathrm{m}$ wide. Ostioles apical, not fused, flat, grey, surrounded by a white spot. Hamathecium inspersed with hyaline oil globules. Asci 8-spored. Ascospores hyaline, 3-septate, narrowly ellipsoid, $21-28 \times 8-10 \mu \mathrm{m}$, ends rounded, lumina diamond-shaped, surrounded by a gelatinous layer $\leq 2 \mu \mathrm{m}$ thick.

Pycnidia not observed.

Chemistry. Thallus surface UV-, K-, thallus medulla $\mathrm{K}-$; pseudostromata surface $\mathrm{UV}-$, inner part of pseudostromata $\mathrm{K}-$. TLC: no secondary substances detected.

Etymology. The species is named after its resemblance to $A$. scoria.

Distribution and habitat. So far the species is known only from the type locality in Bolivia, where it has been found in lowland Amazon forest.

Notes. Astrothelium subscoria can be distinguished by its smooth thallus with small single ascomata immersed in the thallus with a white surface, with apical and not fused ostioles, an inspersed hamathecium, small 3-septate ascosores and the absence of substances. The most similar species, $A$. bicolor Aptroot \& Lücking and $A$. scoria, formerly referred to the Trypethelium nitidiusculumcomplex, differ by the presence of whitish pseudostromata, and in the case of $A$. bicolor, additionally by a not inspersed hamathecium (Aptroot et al. 2008; Aptroot \& Lücking 2016).

\section{Astrothelium variabile Flakus \& Aptroot sp. nov.}

\section{MycoBank No.: MB 812955}

Differs from Astrothelium ochroleucoides Aptroot \& M. Cáceres in the longer ascospores.

Type: Bolivia, Dept. Beni, Prov. Yacuma, RB Estación Biológica del Beni, near biological station, $14^{\circ} 51^{\prime} 07 " \mathrm{~S}, 66^{\circ} 20^{\prime} 23^{\prime \prime} \mathrm{W}, 175 \mathrm{~m}$, island of lowland Amazon forest among Moxos savannah, corticolous, 6 November 2010, A. Flakus 17883 \& F. Saavedra (KRAM-holotype; LPB-isotype).

\section{(Figs 5A \& 6A)}

Thallus corticate, with corticiform layer $\leq c$. $60 \mu \mathrm{m}$ thick, smooth to somewhat bullate, somewhat shiny, continuous, not inducing swellings of the host bark, covering areas $\leq 5 \mathrm{~cm}$ diam., c. $0.8 \mathrm{~mm}$ thick, green to yellowish green, not surrounded by a black prothallus.

Pseudostromata with a surface different from the thallus, not distinctly raised above the thallus, irregular in outline and with sloping sides, $2-10 \times 1-3 \mathrm{~mm}$ and $0.8 \mathrm{~mm}$ high, white, inside without pigments, but containing bark tissue. Ascomata subglobose, 0.5-1.0 mm diam., mostly aggregated, immersed in pseudostromata. Wall fully carbonized, not differentiated into excipulum and involucrellum, $\leq c$. $100 \mu \mathrm{m}$ wide. Ostioles apical, not fused, flat, black, surrounded by a white spot. Hamathecium clear. Asci 8-spored. Ascospores hyaline, I- or I+ violet, densely muriform, without distinctly thickened median septa, narrowly ellipsoid, 110-170 × 20-30 $\mu \mathrm{m}$, ends rounded, lumina diamond-shaped, not surrounded by a gelatinous layer. 

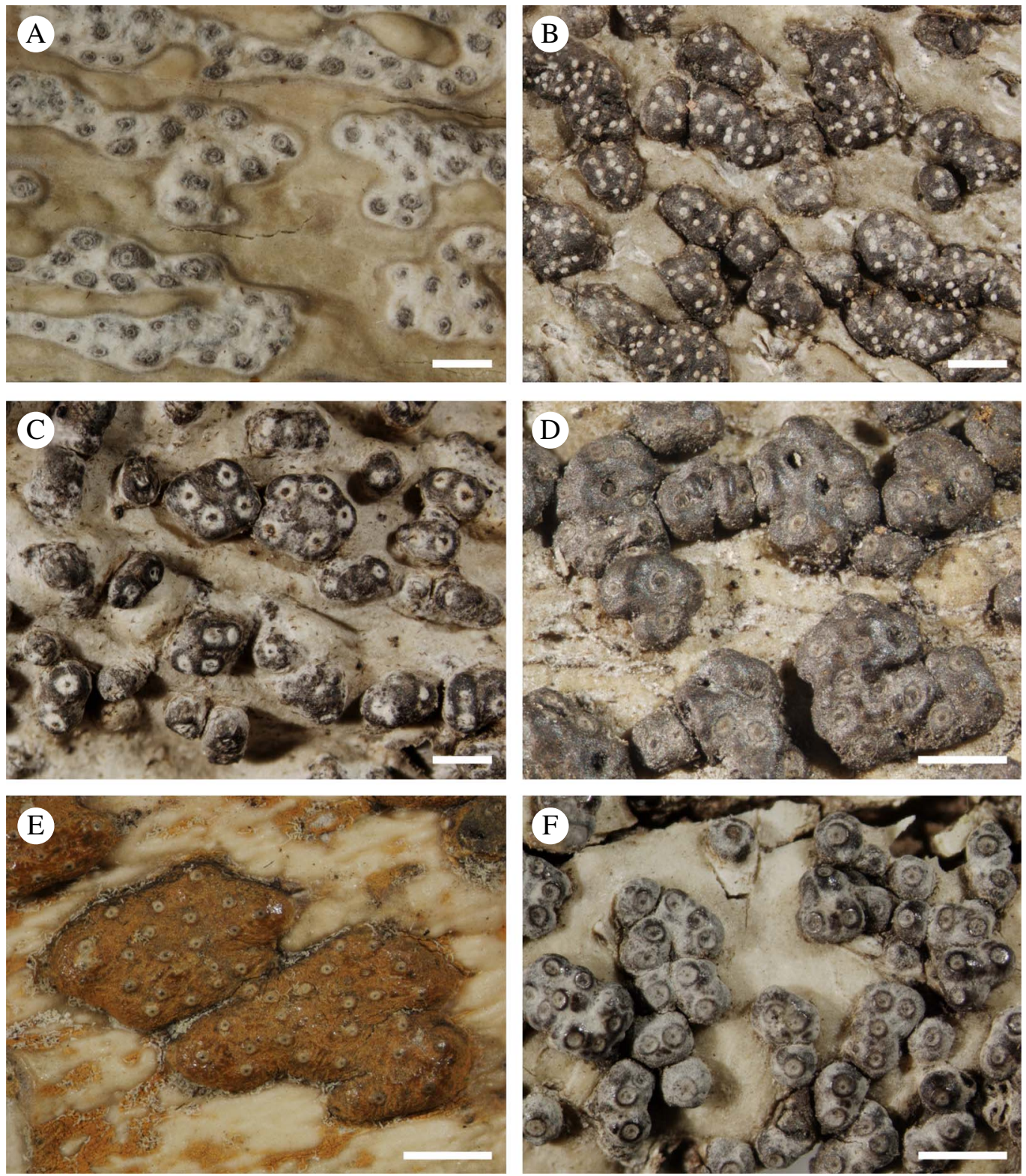

FIG. 5. Habitus of new species of Trypetheliaceae from Bolivia (holotypes). A, Astrothelium variabile; B, Bathelium boliviense; C, B. flavostiolatum; D, B. inspersomastoideum; E, B. mirabile; F, B. pruinosum. Scales = $1 \mathrm{~mm}$. In colour online.

\section{Pycnidia not observed.}

Chemistry. Thallus surface UV+ yellow (whole or in part), $\mathrm{K}+$ yellowish, thallus medulla $\mathrm{K}-$; pseudostromata surface UV+ yellow (whole or in part), inner part of pseudostromata K-. TLC: lichexanthone (major) detected.

Etymology. The specific epithet refers to the variable concentration of lichexanthone in different parts of the thallus. 

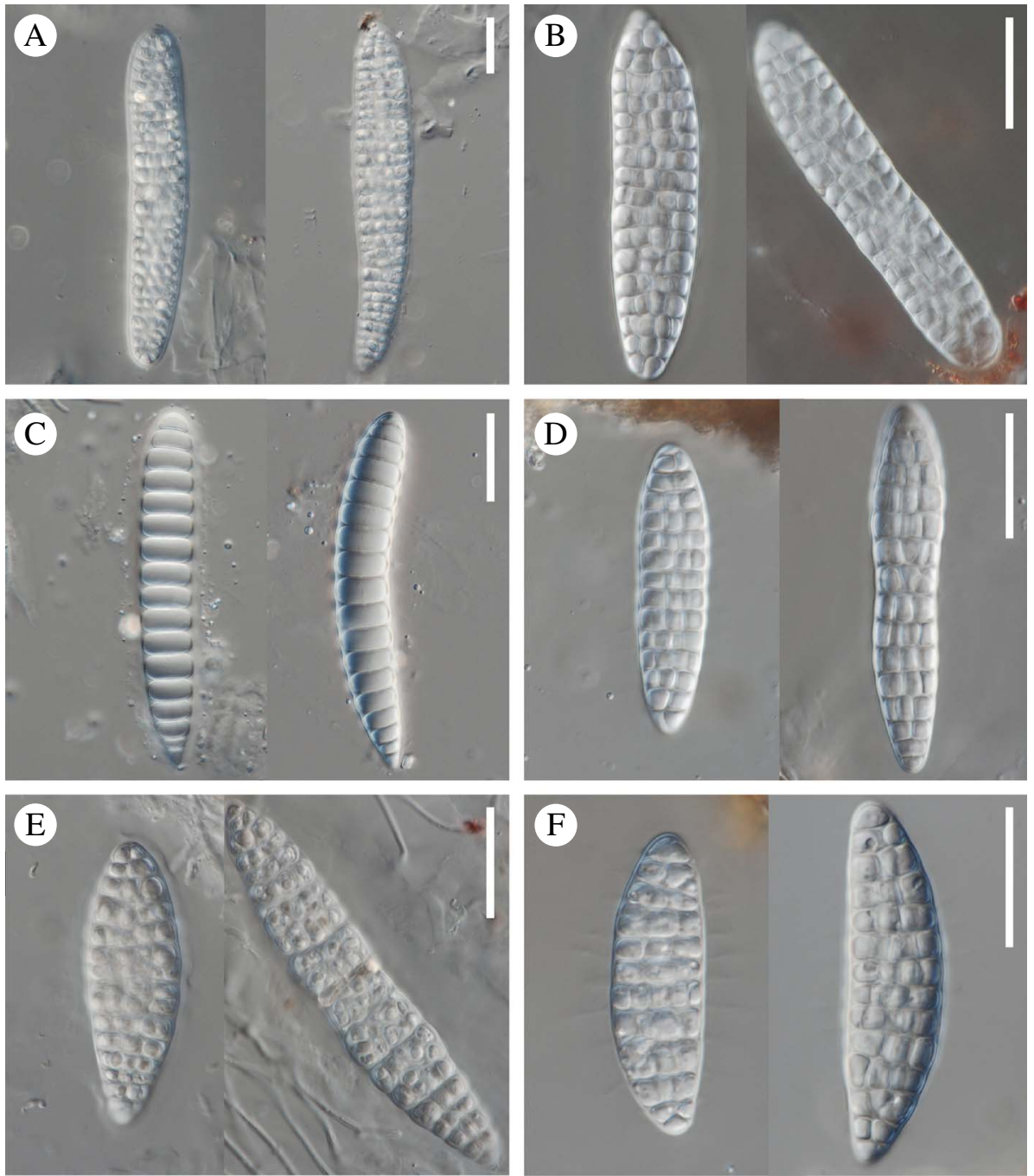

FIG. 6. Ascospores in new species of Trypetheliaceae from Bolivia (holotypes). A, Astrothelium variabile; B, Bathelium boliviense; C, B. flavostiolatum; D, B. inspersomastoideum; E, B. mirabile; F, B. pruinosum. Scales $=25 \mu \mathrm{m}$. In colour online.

Distribution and habitat. So far the species is known only from Bolivia, where it grows in lowland Amazon forest and in islands of Amazon forest in Moxos savannah.

Notes. Astrothelium variabile is characterized by aggregated ascomata immersed in well-delimited pseudostromata with a white surface, apical and not fused ostioles which are black and surrounded by a white spot, a clear hamathecium, narrowly ellipsoid nonamyloid ascospores and lichexanthone as the major substance. Astrothelium ochroleucoides is most similar to the new species, but it has generally smaller $(85-15 \mu \mathrm{m}$ long) ascospores (Aptroot \& Cáceres 2016).

Additional specimens examined. Bolivia: Dept. Beni: Prov. Yacuma, RB Estación Biológica del Beni, near biological station, $14^{\circ} 51^{\prime} 07^{\prime \prime S}, 66^{\circ} 20^{\prime} 23^{\prime \prime} \mathrm{W}, 175 \mathrm{~m}$, island of lowland Amazon forest among Moxos 
savannah, corticolous, 2010, A. Flakus 17866, 17934 \& F. Saavedra (KRAM, LPB, hb. Flakus). Dept. Santa Cruz: Prov. José Miguel de Velasco, sendero de goma near Florida village, $14^{\circ} 37^{\prime} 48^{\prime \prime} \mathrm{S}, 61^{\circ} 12^{\prime} 02^{\prime \prime} \mathrm{W}, 170 \mathrm{~m}$, lowland Amazon secondary forest, corticolous, 2009, A. Flakus 16108 \& P. Rodriguez (LPB).

\section{Bathelium boliviense Flakus \& Aptroot sp. nov.}

MycoBank No.: MB 812958

Differs from Bathelium lineare (C. W. Dodge) R. C. Harris by the presence of isohypocrellin inside the pseudostromata.

Type: Bolivia, Dept. Santa Cruz, Prov. Guarayos, RN de Vida Silvestre Ríos Blanco y Negro, Plan de Manejo AISU, $15^{\circ} 01^{\prime} 58^{\prime \prime S}, 62^{\circ} 46^{\prime} 36^{\prime \prime} \mathrm{W}, 242 \mathrm{~m}$, lowland Amazon forest, corticolous, 24 July 2009, A. Flakus 13907 \& P. Rodriguez (KRAM-holotype; LPB, hb. Flakus-isotypes).

\section{(Figs 5B \& 6B)}

Thallus corticate, with corticiform layer $\leq c .20 \mu \mathrm{m}$ thick, smooth to somewhat bullate, somewhat shiny, continuous, not inducing swellings of the host bark, covering areas $\leq 6 \mathrm{~cm}$ diam., c. $0.4 \mathrm{~mm}$ thick, greyish green, not surrounded by a black prothallus.

Pseudostromata with a surface different from the thallus, distinctly raised above the thallus surface, irregular in outline with almost vertical sides, c. $1.5-5.0 \times 1.0-2.5 \mathrm{~mm}$ and $0.6 \mathrm{~mm}$ high, black, inside with a purple-red (K+ green) granular pigment but without bark tissue. Ascomata subglobose, 0.2-0.3 mm diam., mostly aggregated, immersed in pseudostromata. Wall greyish brown to fully carbonized, not differentiated into excipulum and involucrellum, $\leq$ c. $25 \mu \mathrm{m}$ wide. Ostioles apical, not fused, convex, white, not surrounded by a colour spot. Hamathecium clear. Asci with 6-8 ascospores. Ascospores hyaline, I-, densely muriform, narrowly ellipsoid, without distinctly thickened median septa, 70-115 × 17-22 $\mu \mathrm{m}$, ends rounded, lumina diamond-shaped, surrounded by a gelatinous layer $\leq 3 \mu \mathrm{m}$ thick.

Pycnidia not observed.

Chemistry. Thallus surface UV-, K-, thallus medulla $\mathrm{K}-$; pseudostromata surface UV-, granular red-purple pigment in inner part of pseudostromata K+ green. TLC: isohypocrellin (major) with related substances detected.

Etymology. The species is named after the type locality in Bolivia.

Distribution and habitat. So far the species is known only from Bolivia, where it grows in lowland Amazon forest and in islands of Amazon forest in Moxos savannah.

Notes. Bathelium boliviense is characterized by mostly aggregated, small ascomata, immersed in black pseudostromata containing isohypocrellin (red-purple pigment, $\mathrm{K}+$ green) inside, white ostioles (UV-), and narrowly ellipsoid, non-amyloid, muriform ascospores. The new species is very similar to B. lineare (C. W. Dodge) R. C. Harris and B. sphaericum (C. W. Dodge) R. C. Harris in having large muriform ascospores, 8-spored asci and a lack of lichexanthone. However, these species clearly differ in the lack of isohypocrellin in the pseudostromata and, in the case of $B$. sphaericum, also by having larger ascospores $(130-200 \times 13-20 \mu \mathrm{m})$ (Harris 1995; Aptroot et al. 2008; Aptroot \& Lücking 2016). Isohypocrellin is an extremely rare substance in Trypetheliaceae, and is known only from two species in the genus Bathelium, both known only from Bolivia. Besides $B$. boliviense, this pigment is known also in B. mirabile, which can be easily distinguished by its large pseudostromata covered by parietin (K+ purple, UV+ orange-red).

Additional specimens examined. Bolivia: Dept. Beni: Prov. Yacuma, RB Estación Biológica del Beni, near biological station, $14^{\circ} 51^{\prime} 07^{\prime \prime S}, 66^{\circ} 20^{\prime} 23^{\prime \prime} \mathrm{W}, 175 \mathrm{~m}$, island of lowland Amazon forest among Moxos savannah, corticolous, 2010, A. Flakus 17921 \& F. Saavedra (KRAM, LPB).

\section{Bathelium flavostiolatum Flakus \& Aptroot sp. nov.}

MycoBank No.: MB 812959

Differs from all other Bathelium species by the presence of lichexanthone near the ostioles (tops of pseudostromata UV+ yellow) and an orange ( $\mathrm{K}+$ carmine red) 
pigment inside the pseudostromata, the absence of lichexanthone in the thallus (thallus UV-), an inspersed hamathecium and 13-17-septate ascospores.

Type: Bolivia, Dept. Santa Cruz, Prov. Guarayos, RN de Vida Silvestre Ríos Blanco y Negro, Plan de Manejo AISU, $15^{\circ} 09^{\prime} 13^{\prime \prime S}, 62^{\circ} 47^{\prime} 57^{\prime \prime W}, 240 \mathrm{~m}$, lowland Amazon forest, corticolous, 24 July 2009, A. Flakus 13747 \& P. Rodriguez (KRAM - holotype; LPB - isotype).

\section{(Figs 5C \& 6C)}

Thallus corticate, with corticiform layer c. $30-40 \mu \mathrm{m}$ thick, smooth to somewhat bullate, somewhat shiny, continuous, not inducing swellings of the host bark, covering areas $\leq 10 \mathrm{~cm}$ diam., c. $0.4 \mathrm{~mm}$ thick, greyish green, not surrounded by a black prothallus.

Pseudostromata with a surface different from the thallus, distinctly raised above the thallus surface, irregular in outline constricted with slanting or with almost vertical sides, c. $0.8-1.5 \times 1.5-2.5 \mathrm{~mm}$ diam. and $1 \mathrm{~mm}$ high, black, inside with an orange granular pigment but without bark tissue. Ascomata pyriform, 0.3-0.6 mm diam., mostly aggregated, immersed in pseudostromata. Wall fully carbonized, not differentiated into excipulum and involucrellum, $\leq c .100 \mu \mathrm{m}$ wide. Ostioles apical, not fused, flat, black, surrounded by a white spot. Hamathecium inspersed with hyaline oil globules. Asci 8-spored. Ascospores hyaline, I-, 13-17-septate, narrowly ellipsoid to fusiform, $65-105 \times 13-17 \mu \mathrm{m}$, ends rounded, lumina diamond-shaped, not surrounded by a gelatinous layer.

Pycnidia not observed.

Chemistry. Thallus surface UV-, thallus medulla $\mathrm{K}-$; pseudostromata surface UV-, white spots near ostioles UV+ yellow, granular orange pigment inside of pseudostromata $\mathrm{K}+$ carmine red. TLC: lichexanthone (major) and two dull yellow unidentified anthraquinones with Rf class values A3, B3, C3 and A2, B1-2, C1-2 (dull orange in $366 \mathrm{UV}$ after heating) detected.

Etymology. The specific epithet refers to the presence of lichexanthone near the ostioles.
Distribution and habitat. So far the species is known only from Bolivia, where it grows in lowland Amazon forest and in islands of Amazon forest in Moxos savannah.

Notes. The features of B. flavostiolatum, which distinguish the species from all other members of the genus, are: black pseudostromata with ostioles surrounded by white spots containing lichexanthone (tops of pseudostromata UV+ yellow), inside with an unknown orange granular pigment $(\mathrm{K}+$ carmine red), the absence of lichexanthone in the thallus (thallus UV-), an inspersed hamathecium and 13-17-septate ascospores. Lichexanthone is also produced by Astrothelium ochroleucoides Aptroot \& Lücking, Bathelium pruinosum Flakus et al. and Astrothelium xanthosuperbum Aptroot \& Lücking; however, in these species this substance is present in the whole thallus, whereas in B. flavostiolatum it is only near the ostioles. In addition, these three species can be distinguished by their muriform ascospores (Aptroot \& Lücking 2016).

Additional specimen examined. Bolivia: Dept. Beni: Prov. Yacuma, RB Estación Biológica del Beni, near biological station, $14^{\circ} 51^{\prime} 07^{\prime \prime S}, 66^{\circ} 20^{\prime} 23^{\prime \prime} \mathrm{W}, 175 \mathrm{~m}$, island of lowland Amazon forest among Moxos savannah, corticolous, 2010, A. Flakus 17911 \& F. Saavedra (LPB).

\section{Bathelium inspersomastoideum Flakus \& Aptroot sp. nov.}

MycoBank No.: MB 812960

Differs from Bathelium mastoideum Ach. in having an inspersed hamathecium.

Type: Bolivia, Dept. Santa Cruz, Prov. Guarayos, RN de Vida Silvestre Ríos Blanco y Negro, Plan de Manejo AISU, $15^{\circ} 01^{\prime} 58^{\prime \prime S}, 62^{\circ} 46^{\prime} 36^{\prime \prime} \mathrm{W}, 242 \mathrm{~m}$, lowland Amazon forest, corticolous, 24 July 2009, A. Flakus 13882 \& P. Rodriguez (KRAM - holotype; LPB - isotype).

\section{(Figs 5D \& 6D)}

Thallus corticate, with corticiform layer $\leq c$. $60 \mu \mathrm{m}$ thick, smooth to somewhat bullate, somewhat shiny, continuous, not inducing swellings of the host bark, covering areas $\leq 5 \mathrm{~cm}$ diam., c. $0.8 \mathrm{~mm}$ thick, olive-green, surrounded by a black prothallus. 
Pseudostromata with a surface different from the thallus, distinctly raised above the thallus, irregular in outline with almost vertical to basally constricted sides, $c$. 1-2 $\times 1-5 \mathrm{~mm}$ and $1 \mathrm{~mm}$ high, dark brown to greyish brown, inside with an orange granular pigment but without bark tissue. Ascomata subglobose, $0.3-0.5 \mathrm{~mm}$ diam., mostly aggregated, immersed in pseudostromata. Wall fully carbonized, not differentiated into excipulum and involucrellum, $\leq c$. $80 \mu \mathrm{m}$ wide. Ostioles apical, not fused, flat, black, surrounded by a pale brown spot. Hamathecium inspersed with hyaline oil globules. Asci 8-spored. Ascospores hyaline, I-, densely muriform, narrowly ellipsoid to fusiform, 45-82 $\times 12-17 \mu \mathrm{m}$, ends rounded, lumina diamond-shaped, sometimes surrounded by a gelatinous layer $\leq 5 \mu \mathrm{m}$ thick.

\section{Pycnidia not observed.}

Chemistry. Thallus surface UV-, K-, thallus medulla $\mathrm{K}-$; pseudostromata surface UV - , granular orange pigment in inner part of pseudostromata $\mathrm{K}+$ carmine red. TLC: three unidentified ice blue spots (major) and an unidentified anthraquinone (minor) detected.

Etymology. The specific epithet refers to the inspersed hamathecium and the similarity to B. mastoideum.

Distribution and habitat. So far the species is known only from lowland Amazon forests in Bolivia.

Notes. Bathelium inspersomastoideum is characterized by mostly aggregated ascomata, immersed in pseudostromata with a dark brown surface and an orange granular pigment inside ( $\mathrm{K}+$ carmine red), flat black ostioles surrounded by a pale brown spot, an inspersed hamathecium, and muriform, narrowly ellipsoid ascospores. Bathelium mastoideum is morphologically the most similar species, but it can be distinguished by its clear hymenium (Aptroot et al. 2008; Aptroot \& Lücking 2016).

Additional specimen examined. Bolivia: Dept. Santa Cruz: Prov. Guarayos, RN de Vida Silvestre Ríos Blanco y Negro, Virgen de Pilar near Chonta village, $15^{\circ} 38^{\prime} 54^{\prime \prime S}$,
62 $2^{\circ} 7^{\prime} 37^{\prime \prime W}, 229 \mathrm{~m}$, lowland Amazon forest, corticolous, 2009, A. Flakus 13111 \& P. Rodriguez (LPB).

\section{Bathelium mirabile Flakus, Kukwa \& Aptroot sp. nov.}

MycoBank No.: MB 812961

Differs from other Bathelium species in the pseudostromata containing isohypocrellin inside and parietin outside.

Type: Bolivia, Dept. Beni, Prov. Yacuma, RB Estación Biológica del Beni, near biological station, $14^{\circ} 51^{\prime} 07^{\prime \prime S}, 66^{\circ} 20^{\prime} 23^{\prime \prime} \mathrm{W}, 175 \mathrm{~m}$, island of lowland Amazon forest among Moxos savannah, corticolous, 6 November 2010, A. Flakus 17922 \& F. Saavedra (KRAM-holotype; LPB - isotype).

\section{(Figs 5E \& 6E)}

Thallus corticate, with corticiform layer $\leq c$. $60 \mu \mathrm{m}$ thick, smooth, somewhat shiny, continuous, not inducing swellings of the host bark, covering areas $\leq 7 \mathrm{~cm}$ diam., c. $0.3 \mathrm{~mm}$ thick, yellowish green and partly orange, not surrounded by a black prothallus.

Pseudostromata with a surface different from the thallus, distinctly raised above the thallus, irregular in outline with almost vertical to basally constricted sides, c. $0.8-2.5 \times 1.5-6.0 \mathrm{~mm}$ and $0.7 \mathrm{~mm}$ high, orange, inside with a granular purple-red pigment, but without bark tissue. Ascomata pyriform, $0.2-0.4 \mathrm{~mm}$ diam., aggregated, immersed in pseudostromata. Wall fully carbonized, not differentiated into excipulum and involucrellum, $\leq c . \quad 30 \mu \mathrm{m}$ wide. Ostioles apical, not fused, flat, white. Hamathecium clear. Asci with 4-(8) ascospores. Ascospores hyaline, I-, densely muriform, narrowly ellipsoid to fusiform, 60-120 ×15-24 $\mu \mathrm{m}$, ends rounded, lumina diamond-shaped, not surrounded by a gelatinous layer.

Pycnidia not observed.

Chemistry. Thallus surface in small part $\mathrm{UV}+$ orange, $\mathrm{K}+$ purple, thallus medulla $\mathrm{K}-$; pseudostromata surface $\mathrm{UV}+$ orange, $\mathrm{K}+$ purple, granular red-purple pigment inside of pseudostromata $\mathrm{K}+$ green. TLC: parietin (major), isohypocrellin (major) with related substances and an unidentified anthraquinone (minor) detected. 
Etymology. The specific epithet refers to the unusual combination of pigments in the pseudostromata of the new species.

Distribution and habitat. So far the species is known only from Bolivia, where it grows in lowland Amazon forest and in islands of Amazon forest in Moxos savannah.

Notes. The unusual combination of pigments in the pseudostromata of Bathelium mirabile makes this species unmistakable in the genus. It is characterized by aggregated ascomata, immersed in large pseudostromata covered by parietin (orange pigment $\mathrm{K}+$ purple, UV+ orange-red), the presence of isohypocrellin inside (red-purple pigment $\mathrm{K}+$ green), and narrowly ellipsoid, muriform ascospores.

Additional specimens examined. Bolivia: Dept. Santa Cruz: Prov. Ichilo, Parque Nacional y Área Natural de Manejo Integrado Amboró, Macuñucu settlement, $17^{\circ} 43^{\prime} 38^{\prime \prime} \mathrm{S}, 63^{\circ} 35^{\prime} 37^{\prime \prime} \mathrm{W}, 460 \mathrm{~m}$, lowland Amazon forest, corticolous, 2011, M. Kukwa 9706 (LPB, UGDA).

\section{Bathelium pruinosum Flakus, Kukwa \& Aptroot sp. nov.}

MycoBank No.: MB 812962

Differs from Astrothelium ochroleucoides Aptroot \& M. Cáceres in having 8-spored asci, shorter ascospores, an inspersed hamathecium, and an unidentified anthraquinone (orange pigment $\mathrm{K}+$ carmine red) inside the pseudostromata.

Type: Bolivia, Dept. Beni, Prov. José Ballivián, north of San Borja, $14^{\circ} 46^{\prime} 07^{\prime \prime S}, 66^{\circ} 46^{\prime} 51^{\prime \prime W}, 190 \mathrm{~m}$, lowland Amazon forest surrounded by Moxos savannah, corticolous, 3 September 2012, M. Kukwa 12052 (UGDAholotype; LPB - isotype).

\section{(Figs $5 \mathrm{~F} \& 6 \mathrm{~F}$ )}

Thallus corticate, with corticiform layer c. $20-30 \mu \mathrm{m}$ thick, smooth to somewhat bullate, matt, whitish-pruinose, continuous, not inducing swellings of the host bark, covering areas $\leq 5 \mathrm{~cm}$ diam., c. $0.2 \mathrm{~mm}$ thick, greyish to yellowish green, not surrounded by a black prothallus.

Pseudostromata with a surface different from the thallus, distinctly raised above the thallus surface, irregular in outline, with almost vertical to basally constricted sides, c. 1-2 $\times 1-4 \mathrm{~mm}$ and $0.6 \mathrm{~mm}$ high, black, white-pruinose, inside with a granular orange pigment, but without bark tissue. Ascomata subglobose, $0.3-0.5 \mathrm{~mm}$ diam., mostly aggregated, immersed in pseudostromata. Wall fully carbonized, not differentiated into excipulum and involucrellum, $\leq c .60 \mu \mathrm{m}$ wide. Ostioles apical, not fused, flat, black, surrounded by a greyish spot. Hamathecium inspersed with hyaline oil globules. Asci 8-spored. Ascospores hyaline, I-, densely muriform, broadly ellipsoid to fusiform, 45-70 × 13-20 $\mu \mathrm{m}$, ends rounded, lumina diamond-shaped, not surrounded by a gelatinous layer.

Pycnidia not observed.

Chemistry. Thallus surface UV+ yellow, $\mathrm{K}-$, thallus medulla $\mathrm{K}-$; pseudostromata surface UV+ yellow, granular orange pigment in inner part of pseudostromata $\mathrm{K}+$ carmine red. TLC: lichexanthone (major), three unidentified ice blue spots (minor) and an unidentified anthraquinone (minor) detected.

Etymology. The specific epithet refers to the strongly pruinose thallus and pseudostromata.

Distribution and habitat. So far the species is known only from Bolivia, where it grows in dry Chaqueño forest and in islands of Amazon forest in Moxos savannah.

Notes. Bathelium pruinosum is characterized by a white pruinose thallus, mostly aggregated ascomata immersed in black, white-pruinose pseudostromata containing a granular orange pigment inside $(\mathrm{K}+$ carmine red), an inspersed hamathecium, broadly ellipsoid, muriform ascospores, and lichexanthone as a major substance (thallus and pseudostromata UV+ yellow). The most similar species is Astrothelium ochroleucoides, which can be simply distinguished by its larger ascospores $(80-115 \times 15-24 \mu \mathrm{m})$, 8 -spored asci, and not inspersed hamathecium (Aptroot \& Lücking 2016). 
Additional specimens examined. Bolivia: Dept. Santa Cruz: Prov. Cordillera, Parque Nacional y Área Natural de Manejo Integrado Kaa-Iya del Gran Chaco, park guard's station near Peto Blanco, 18 $511^{\prime} 36 " \mathrm{~S}$, $60^{\circ} 18^{\prime} 00^{\prime \prime W}, 290 \mathrm{~m}$, transition Chiquitano-Chaqueño forest, corticolous, 2011, A. Flakus 23709 (KRAM, LPB); $18^{\circ} 48^{\prime} 25^{\prime \prime} \mathrm{S}, 60^{\circ} 14^{\prime} 54^{\prime \prime} \mathrm{W}, 330 \mathrm{~m}$, transition ChiquitanoChaqueño forest, corticolous, 2011, M. Kukwa 10679 (LPB, UGDA).

\section{Constrictolumina chiquitana Flakus, Kukwa \& Aptroot sp. nov.}

MycoBank No.: MB 818240

Differs from other known Constrictolumina species in having brown and 1-septate to submuriform ascospores.

Type: Bolivia, Dept. Santa Cruz, Prov. Cordillera, Parque Nacional y Área Natural de Manejo Integrado Kaa-Iya del Gran Chaco, park guard's station near Peto Blanco, $18^{\circ} 56^{\prime} 26^{\prime \prime S}, 60^{\circ} 22^{\prime} 39^{\prime \prime} \mathrm{W}, 340 \mathrm{~m}$, Chiquitano forest, 5 December 2011, M. Kukwa 10621 (UGDAholotype; LPB, ABL-isotypes).

\section{(Figs 7A \& 8A)}

Thallus ecorticate, endophloeodal, smooth, continuous, not inducing swellings of the host bark, covering areas $\leq 15 \mathrm{~cm}$ diam., c. $0.1 \mathrm{~mm}$ thick, greyish white, not surrounded by a black prothallus.

Ascomata subglobose, $0.3-0.5 \mathrm{~mm}$ diam., single, ascomatal verrucae usually elongate in outline, almost flat to hemispherical emergent from the thallus to superficial with a surface different from the thallus, greyish black, covered by an extending clypeus c. $0 \cdot 6-1.4 \mathrm{~mm}$ wide and $120 \mu \mathrm{m}$ thick, ascomatal base immersed in the bark. Wall fully carbonized, differentiated into pseudoparenchymatic excipulum, $\leq c .40 \mu \mathrm{m}$ wide, and involucrellum, $c$. $30-60 \mu \mathrm{m}$ wide; involucrellum strongly horizontally expanded into clypeus. Ostioles apical, not fused, flat, black, surrounded by a greyish spot. Hamathecium clear. Asci 8-spored. Ascospores brown, $\mathrm{K}+$ grey, 1-septate to submuriform, narrowly ellipsoid, constricted, $26-48 \times 12-17 \mu \mathrm{m}$, ends rounded, lumina rounded, wall $0 \cdot 2-0.4 \mu \mathrm{m}$ thick, not surrounded by a gelatinous layer, delicately ornamented by fine verrucae.
Pycnidia not observed.

Chemistry. Thallus surface $\mathrm{UV}-, \mathrm{K}-$, thallus medulla $\mathrm{K}-$; ascomata UV-. TLC: no secondary substances detected.

Etymology. The species is named after the vegetation in which the type specimen was collected.

Distribution and habitat. So far the species is known only from the type locality in Bolivia, where it grows in lowland dry Chiquitano forest.

Notes. Constrictolumina chiquitana is characterized by an ecorticate, endophloeodal thallus, single, greyish black ascomata covered by an extended clypeus, apical ostioles, a clear hamathecium, and brown 1-septate to submuriform ascospores. It is so far the only species in the genus with pigmented ascospores. However, it is not the only genus of Trypetheliaceae in which species possess both hyaline and brown ascospores. This phenomenon is also known in Architrypethelium (Aptroot et al. 2008). The new species is described in the genus Constrictolumina primarily because of the similarity in hamathecium structure.

\section{Dictyomeridium lueckingii Flakus \& Aptroot sp. nov.}

\section{MycoBank No.: MB 818241}

Differs from Dictyomeridium proponens (Nyl.) Aptroot \& Lücking in having smaller and less septate ascospores.

Type: Bolivia, Dept. Tarija, Prov. Burnet O'Connor, $24 \mathrm{~km}$ from Entre Ríos near Soledad, 2139'45"S, $64^{\circ} 07^{\prime} 29^{\prime \prime} \mathrm{W}, 1700 \mathrm{~m}$, Tucumano-Boliviano montane forest, corticolous, 11 August 2012, A. Flakus 24211 (KRAM-holotype; ABL, LPB, hb. Flakus - isotypes).

(Figs 7B \& 8B)

Thallus ecorticate, smooth, cracked, matt, somewhat white pruinose, continuous, not inducing swellings of the host bark, covering areas $\leq 10 \mathrm{~cm}$ diam., c. $0.2 \mathrm{~mm}$ thick, white, not surrounded by a black prothallus.

Ascomata pyriform, $0.2-0.4 \mathrm{~mm}$ diam., single, half immersed, with a surface different from the thallus, ascomatal verrucae 

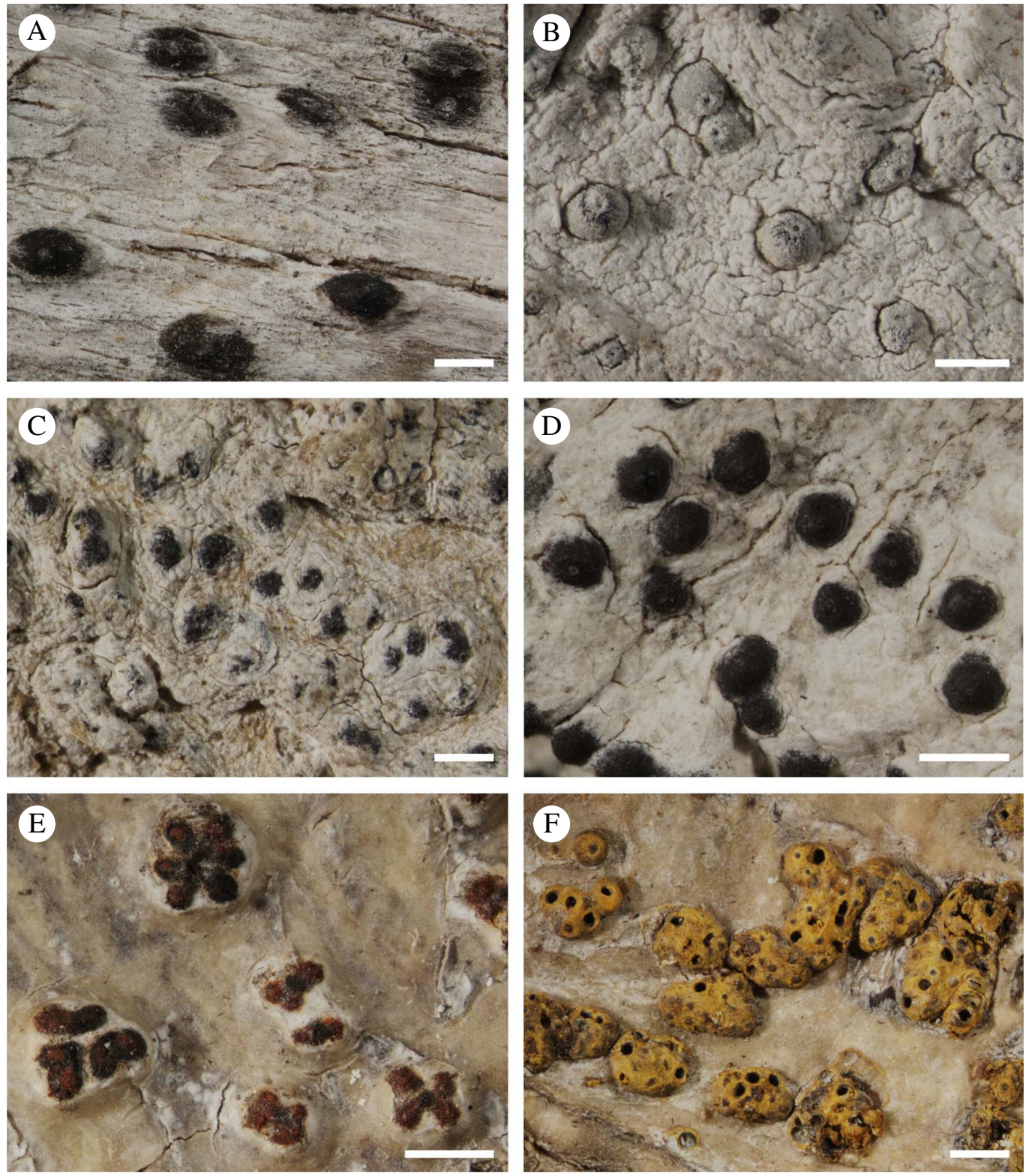

FIG. 7. Habitus of new species of Trypetheliaceae from Bolivia (holotypes). A, Constrictolumina chiquitana; B, Dictyomeridium lueckingii; C, Polymeridium xanthoexcentricum; D, Pseudopyrenula flavosuperans; E, Trypethelium astroideum; F, T. xanthoplatystomum. Scales: A, D, E \& F = $1 \mathrm{~mm}$; B \& C = 0.5 mm. In colour online.

distinctly raised above the thallus, grey (black but white pruinose). Wall fully carbonized, not differentiated into excipulum and involucrellum, $\leq c .80 \mu \mathrm{m}$ wide. Ostioles eccentric, not fused, beaked, black, surrounded by a greyish spot. Hamathecium clear. Asci 8-spored. Ascospores hyaline, I+ violet, submuriform, with 5-6 transverse and 1-2 longitudinal septa, 8-13-celled, broadly ellipsoid, $25-35 \times 12-17 \mu \mathrm{m}$, ends 
rounded, lumina rounded, surrounded by a gelatinous layer $\leq 4 \mu \mathrm{m}$ thick.

Pycnidia not observed.

Chemistry. Thallus surface UV+ yellow, thallus medulla $\mathrm{K}-$; ascomata surface UV+ yellow. TLC: lichexanthone (major) detected.

Etymology. The new species is named in honour of our friend Dr Robert Lücking (Chicago), the prominent German lichenologist, for his magnificent contribution to the knowledge of tropical lichens, on the occasion of his 50th birthday.

Distribution and habitat. So far the species is known only from the type locality in Bolivia, where it has been found in TucumanoBoliviano montane forest.

Notes. Dictyomeridium lueckingii is characterized by an ecorticate and somewhat pruinose thallus, pyriform, half immersed, single, black and white-pruinose ascomata, eccentric, beaked ostioles, a clear hamathecium, hyaline, amyloid, small submuriform ascospores and the presence of lichexanthone (thallus and ascomata surface UV+ yellow).

The most similar species, $D$. proponens and D. paraproponens Aptroot et al., can be distinguished by larger ascospores, which measure $35-54 \times 12-19 \mu \mathrm{m}$ and $55-75 \times$ 19-21 $\mu \mathrm{m}$ respectively (Aptroot et al. 2008; Aptroot \& Lücking 2016).

\section{Polymeridium xanthoexcentricum Flakus \& Aptroot sp. nov.}

\section{MycoBank No.: MB 812963}

Differs from Polymeridium alboflavescens Aptroot in having mostly eccentric ostioles.

Type: Bolivia, Dept. Santa Cruz, Prov. Cordillera, Parque Nacional y Área Natural de Manejo Integrado Kaa-Iya del Gran Chaco, gasoducto Bolivia-Brasil, near Tucavaca colony, 18³0'19"S, 6057'14"W, 278 m, Chiquitano forest, corticolous, 4 December 2010, A. Flakus 18991 \& F. Quisbert (LPB-holotype).

\section{(Figs 7C \& 8C)}

Thallus ecorticate, in part endophloeodal, smooth to somewhat bullate, continuous, not inducing swellings of the host bark, covering areas $\leq 6 \mathrm{~cm}$ diam., c. $0.3 \mathrm{~mm}$ thick, grey, not surrounded by a black prothallus.

Ascomata subglobose, $0.2-0.5 \mathrm{~mm}$ diam., mainly single or sometimes $2-3$ fused with partly shared walls, black, ascomatal verrucae barely raised above the thallus, hemispherical to irregular in outline with sloping sides, ascomatal base often deeply immersed in the bark. Wall fully carbonized, not differentiated into excipulum and involucrellum, at the upper half $\leq c$. $100 \mu \mathrm{m}$ wide. Ostioles mainly eccentric, sometimes fused, flat, black. Hamathecium clear. Asci with 4-8 ascospores. Ascospores hyaline, I-, 7-10-septate, fusiform, 30-50 $\times 6.5-8.0 \mu \mathrm{m}$, ends rounded, lumina rounded, surrounded by a gelatinous layer $\leq 2 \mu \mathrm{m}$ thick.

Pycnidia not observed.

Chemistry. Thallus surface UV+ yellow, thallus medulla $\mathrm{K}-$; pseudostromata surface UV-. TLC: lichexanthone (major) detected.

Etymology. The name refers to the presence of lichexanthone in the thallus (UV+ yellow) and the mostly eccentric ostioles.

Distribution and habitat. So far the species is known only from Bolivia, where it grows in lowland dry Chiquitano forest.

Notes. Polymeridium xanthoexcentricum is characterized by an ecorticate, in part endophloeodal thallus, mainly single or $2-3$ aggregated ascomata, partly covered by the thallus, eccentric ostioles, a clear hamathecium, 7-10-septate, fusiform ascospores and the presence of lichexanthone as a major substance (thallus UV+ yellow). It is most similar to $P$. alboflavescens, which can be distinguished by its clearly apical ostioles and slightly flattened tops of the ascomata (Aptroot \& Cáceres 2014; Aptroot \& Lücking 2016).

\section{Pseudopyrenula flavosuperans Flakus \& Aptroot sp. nov.}

MycoBank No.: MB 812964

Differs from Pseudopyrenula superans Müll. Arg. in having a hamathecium inspersed with yellow oil globules. 

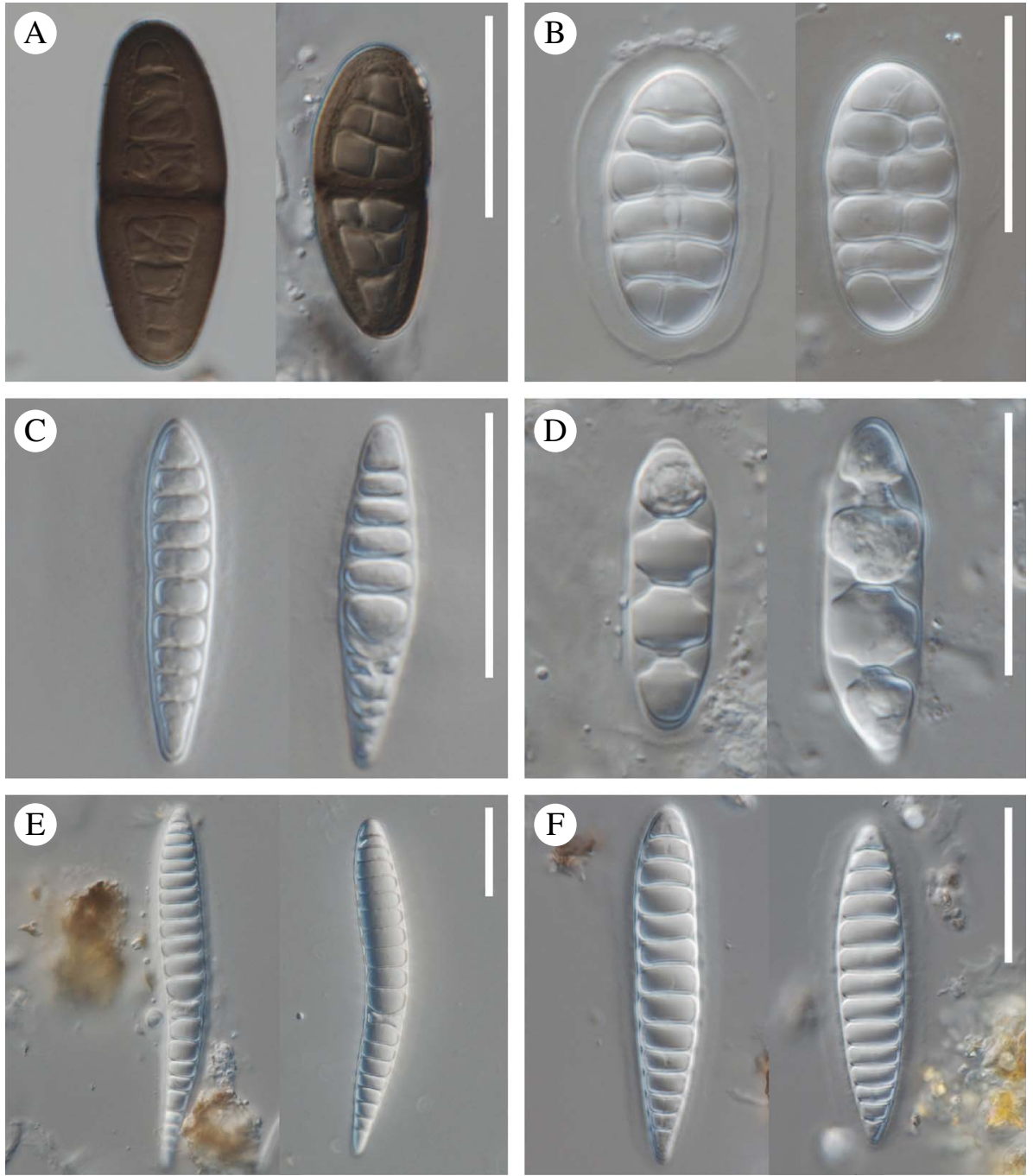

FIG. 8. Ascospores in new species of Trypetheliaceae from Bolivia (holotypes). A, Constrictolumina chiquitana; B, Dictyomeridium lueckingii; C, Polymeridium xanthoexcentricum; D, Pseudopyrenula flavosuperans; E, Trypethelium astroideum; F, T. xanthoplatystomum. Scales $=25 \mu \mathrm{m}$. In colour online.

Type: Bolivia, Dept. Beni, Prov. José Ballivián, near Reyes village, $14^{\circ} 18^{\prime} 10^{\prime \prime} \mathrm{S}, 67^{\circ} 18^{\prime} 49^{\prime \prime} \mathrm{W}, 185 \mathrm{~m}$, Moxos savannah, corticolous, 29 November 2004, A. Flakus 3722 (KRAM - holotype; LPB - isotype).

\section{(Figs 7D \& 8D)}

Thallus ecorticate, smooth, continuous, not inducing swellings of the host bark, covering areas $\leq 6 \mathrm{~cm}$ diam., c. $0 \cdot 2 \mathrm{~mm}$ thick, white, surrounded by a black prothallus.
Ascomata subglobose, $0.6-0.8 \mathrm{~mm}$ diam., solitary, superficial with a surface different from the thallus, ascomatal verrucae distinctly raised above the thallus, hemispherical, with sloping sides, black, often basally immersed in bark. Wall fully carbonized, not differentiated into excipulum and involucrellum, $\leq c .100 \mu \mathrm{m}$ wide. Ostioles apical, not fused, convex, black. Hamathecium inspersed with yellow oil globules. Asci 8-spored. Ascospores 
hyaline, I-, 3-septate, narrowly ellipsoid to fusiform, 26-36 $\times 7-10 \mu \mathrm{m}$, ends rounded, lumina diamond-shaped, not surrounded by a gelatinous layer.

Pycnidia not observed.

Chemistry. Thallus surface UV+ yellow, thallus medulla $\mathrm{K}-$; ascomata surface UV- . TLC: lichexanthone (major) detected.

Etymology. The specific epithet refers to the yellow-inspersed hamathecium and the similarity to $P$. superans.

Distribution and habitat. So far the species is known from various localities in Bolivia, where it grows in the lowland in Moxos savannah and in Amazon forest.

Notes. Pseudopyrenula flavosuperans is characterized by a white, ecorticate thallus containing lichexanthone (UV+ yellow), large, black, solitary and superficial ascomata, a hamathecium inspersed with yellow oil globules, and small 3-septate ascospores. Pseudopyrenula superans has very similar sized ascospores and also contains lichexanthone, but this species can be distinguished by its hamathecium inspersed by hyaline oil globules (Aptroot \& Lücking 2016).

Additional specimens examined. Bolivia: Dept. Beni: Prov. José Ballivián, near Reyes village, $14^{\circ} 18^{\prime} 10^{\prime \prime} S$, $67^{\circ} 18^{\prime} 49^{\prime \prime} \mathrm{W}, 185 \mathrm{~m}$, Moxos savannah, corticolous, 2004, A. Flakus 4375, 4403, 4424 (KRAM, LPB, hb. Flakus); Prov. Yacuma, RB Estación Biológica del Beni, near biological station, $14^{\circ} 51^{\prime} 07^{\prime \prime} \mathrm{S}, 66^{\circ} 20^{\prime} 23^{\prime \prime} \mathrm{W}, 175 \mathrm{~m}$, island of lowland Amazon forest among Moxos savannah, corticolous, 2010, A. Flakus 17876, 17880, 17932 \& F. Saavedra (ABL, LPB, KRAM, hb. Flakus). Dept. Santa Cruz: Prov. Guarayos, RN de Vida Silvestre Ríos Blanco y Negro, Virgen de Pilar near Chonta village, $15^{\circ} 38^{\prime} 54^{\prime \prime} \mathrm{S}$, $62^{\circ} 57^{\prime} 37^{\prime \prime} \mathrm{W}, 229 \mathrm{~m}$, lowland Amazon forest, corticolous, 2009, A. Flakus 13235 \& P. Rodriguez (LPB).

\section{Trypethelium astroideum Flakus \& Aptroot sp. nov.}

MycoBank No.: MB 812965

Differs from Trypethelium subeluteriae Makhija \& Patw. in having $\mathrm{K}+$ carmine red pseudostromata containing parietin inside, and black tops with an additional unidentified anthraquinone (rust red pigment $\mathrm{K}+$ purple, $\mathrm{UV}-$ ) on the outside, partly fused ostioles, and larger ascospores.
Type: Bolivia, Dept. Santa Cruz, Prov. José Miguel de Velasco, Parque Nacional Noel Kempff Mercado, near Florida village, $14^{\circ} 35^{\prime} 50^{\prime \prime} \mathrm{S}, 61^{\circ} 50^{\prime} 46^{\prime \prime W}, 220 \mathrm{~m}$, Moxos savannah with trees, corticolous, 15 December 2009, A. Flakus 15722 \& P. Rodriguez (KRAM-holotype; LPB - isotypes).

\section{(Figs 7E \& 8E)}

Thallus corticate, with corticiform layer c. $40-80 \mu \mathrm{m}$ thick, smooth to somewhat bullate, inducing swellings of the host bark, somewhat shiny, continuous, covering areas $\leq 7 \mathrm{~cm}$ diam., c. $0.5 \mathrm{~mm}$ thick, olive-green, not surrounded by a black prothallus.

Pseudostromata with a surface similar to the thallus or slightly paler, distinctly raised above the thallus surface, irregular in outline (star-like), with sloping sides, c. 1.0-1.5 $\times 1-$ $3 \mathrm{~mm}$ and $0.8 \mathrm{~mm}$ high, olive-green with paler border and black ostiolar area with rust red pigment, inside with an additional orange granular pigment and bark tissue. Ascomata pyriform, $0.3-0.6 \mathrm{~mm}$ diam., aggregated, immersed in pseudostromata. Wall fully carbonized, not differentiated into excipulum and involucrellum, $\leq c$. $100 \mu \mathrm{m}$ wide. Ostioles eccentric to apical, fused to simple, convex, black, surrounded by a rust red pigmented spot, usually forming a black star-shaped pattern. Hamathecium clear. Asci 8-spored. Ascospores hyaline, I-, 12-22-septate, fusiform, 65-100 $\times 11-14 \mu \mathrm{m}$, ends rounded, lumina rounded, not surrounded by a gelatinous layer.

Pycnidia not observed.

Chemistry. Thallus surface UV-, K-, thallus medulla $\mathrm{K}-$; pseudostromata surface $\mathrm{UV}-$, rust red pigment near ostioles, UV-, $\mathrm{K}+$ purple (not dissolving), granular orange pigment inside of pseudostromata $\mathrm{K}+$ carmine red (dissolving). TLC: parietin (minor) and additional unidentified anthraquinone (trace) detected.

Etymology. The name refers to the star-like arrangement of the perithecia in the pseudostromata.

Distribution and habitat. So far the species has been found only in lowland Bolivia, in Amazon forest and in Moxos savannah. 
Notes. Trypethelium astroideum is a very distinct species owing to its characteristic star-like pseudostromata, clear hamathecium, and 12-22-septate, fusiform ascospores. Its ascomata, with mostly fused ostioles, are aggregated in pseudostromata, which contain parietin $(\mathrm{K}+$ carmine red). The surface of the pseudostromata is covered by the thallus, but the black ostiolar area is covered with an additional rust red pigment ( $\mathrm{K}+$ purple, UV-). It is most similar to $T$. subeluteriae, which clearly differs in its shorter, 13-16-septate ascospores (60-85 $\times 11-12 \mu \mathrm{m})$, not fused ostioles, and in pseudostroma morphology. Some other Trypethelium species without pigments, like T. luteolucidum Aptroot \& Lücking and T. ornatum Müll. Arg. have ascospore sizes similar to $T$. astroideum. The first also differs by an inspersed hamathecium and the presence of lichexanthone, and the last one by the inspersed hamathecium (Aptroot \& Lücking 2016).

Additional specimens examined. Bolivia: Dept. Santa Cruz: Prov. José Miguel de Velasco, Parque Nacional Noel Kempff Mercado, Camino los Fierros near Florida village, $14^{\circ} 32^{\prime} 25^{\prime \prime} \mathrm{S}, \quad 61^{\circ} 03^{\prime} 13^{\prime \prime} \mathrm{W}, 215 \mathrm{~m}$, lowland Amazon forest, corticolous, 2009, A. Flakus 15546 \& P. Rodriguez (KRAM, LPB, hb. Flakus); Prov. Guarayos, RN de Vida Silvestre Ríos Blanco y Negro, Plan de Manejo AISU, $15^{\circ} 01^{\prime} 58^{\prime \prime} \mathrm{S}, 62^{\circ} 46^{\prime} 36^{\prime \prime} \mathrm{W}, 242 \mathrm{~m}$, lowland Amazon forest, corticolous, 2009, A. Flakus 13891 \& P. Rodriguez (KRAM, LPB). Dept. Pando: Prov. Manuripi, RN de Vida Silvestre Amazónica Manuripi, Metale colony near Chive village, close to Río Madre de Dios, $12^{\circ} 20^{\prime} 38^{\prime \prime} \mathrm{S}, 68^{\circ} 20^{\prime} 40^{\prime \prime} \mathrm{W}, 170 \mathrm{~m}$, lowland Amazon forest, corticolous, 2006, A. Flakus 6157.1 (LPB).

\section{Trypethelium xanthoplatystomum Flakus \& Aptroot sp. nov.}

MycoBank No.: MB 812966

Differs from Trypethelium platystomum Mont. by the presence of lichexanthone (UV+ yellow) in the thallus.

Type: Bolivia, Dept. Santa Cruz, Prov. Guarayos, RN de Vida Silvestre Ríos Blanco y Negro, Plan de Manejo AISU, $15^{\circ} 01^{\prime} 58^{\prime \prime} \mathrm{S}, 62^{\circ} 46^{\prime} 36^{\prime \prime} \mathrm{W}, 242 \mathrm{~m}$, lowland Amazon forest, corticolous, 24 July 2009, A. Flakus 13887 \& P. Rodriguez (KRAM-holotype; LPB - isotypes).

(Figs 7F \& 8F)

Thallus corticate, with corticiform layer $\leq c .60 \mu \mathrm{m}$ thick, smooth to somewhat bullate, somewhat shiny, continuous, not inducing swellings of the host bark, covering areas $\leq 4 \mathrm{~cm}$ diam., c. $0.3 \mathrm{~mm}$ thick, yellowish to greyish green, not surrounded by a black prothallus.

Pseudostromata with a surface different from the thallus, distinctly raised above the thallus surface, irregular in outline with almost vertical to basally constricted sides, c. $1.0-1.5 \times 1.5-3.0 \mathrm{~mm}$ and $0.9 \mathrm{~mm}$ high, orange-yellow, inside with a granular yelloworange pigment, but without bark tissue. Ascomata pyriform, $0.3-0.5 \mathrm{~mm}$ diam., aggregated in pseudostromata. Wall greyish to fully carbonized, not differentiated into excipulum and involucrellum, $\leq c .60 \mu \mathrm{m}$ wide. Ostioles apical, not fused, flat, black. Hamathecium clear. Asci 8-spored. Ascospores hyaline, I-, 8-14-septate, fusiform, 45-65 $\times 9-12 \mu \mathrm{m}$, ends rounded, lumina rounded, usually surrounded by a gelatinous layer $\leq 3 \mu \mathrm{m}$ thick.

Pycnidia not observed.

Chemistry. Thallus surface UV+ yellow, thallus medulla $\mathrm{K}-$; pseudostromata surface $\mathrm{UV}+$ orange, $\mathrm{K}+$ purple, granular yelloworange pigment in inner part of pseudostromata K+ carmine red. TLC: lichexanthone (major) and parietin (major) detected.

Etymology. The species is named after the presence of lichexanthone in the thallus and its similarity to $T$. platystomum.

Distribution and habitat. So far the species is known only from Amazon forest and Moxos savannah in Bolivia.

Notes. Trypethelium xanthoplatystomum can be distinguished by its mostly smooth thallus containing lichexanthone (UV+ yellow), ascomata with apical and not fused ostioles, aggregated in orange-yellow pseudostromata (surface $\mathrm{UV}+$ orange, $\mathrm{K}+$ purple), inside with a granular yellow-orange pigment (parietin), a clear hamathecium, and 8-14-septate, fusiform ascospores. The new species is reminiscent of $T$. platystomum, but this lacks lichexanthone (thallus UV-) (Aptroot et al. 2008; Aptroot \& Lücking 2016). 
TABLE 1. Checklist of corticolous lichens of the family Trypetheliaceae from Bolivia.

Species name

Architrypethelium penuriixanthum Flakus \& Aptroot Astrothelium aeneum (Eschw.) Aptroot \& Lücking*

A. amazonum (R. C. Harris) Aptroot \& Lücking

A. amylosporum Flakus \& Aptroot

A. annulare (Mont.) Aptroot \& Lücking $\star$

A. bicolor (Taylor) Aptroot \& Lücking

A. bullatum Flakus \& Aptroot

A. carrascoense Flakus et al.

A. cartilagineum (Fée) Aptroot \& Lücking

A. cinnamomeum (Eschw.) Müll. Arg. *

A. effusum (Aptroot \& Sipman) Aptroot \& Lücking A. elixii Flakus \& Aptroot

A. erubescens (Kunze) Aptroot \& Lücking

A. eustomum (Mont.) Müll. Arg.

A. macrocarpum (Fée) Aptroot \& Lücking ${ }^{\star}$

A. infossum (Nyl.) Aptroot \& Lücking

A. inspersaeneum Aptroot \& M. Cáceres

A. inspersotuberculosum Flakus \& Aptroot

A. megaeneum Flakus \& Aptroot

A. megaspermum (Mont.) Aptroot \& Lücking

A. neodiplocarpum Flakus et al.

A. nigrocacuminum Flakus et al.

A. octosporoides Aptroot \& Lücking

A. olivaceofuscum (Zenker) Aptroot \& Lücking

A. pallidoflavum Flakus et al.

A. papulosum (Nyl.) Aptroot \& Lücking

A. phlyctaena (Fée) Aptroot \& Lücking

A. pyrenuliforme Flakus \& Aptroot

A. scoria (Fée) Aptroot \& Lücking

A. scorioides $\mathrm{Nyl}$.

A. sepultum Mont.

A. stromatofluorescens Aptroot \& M. Cáceres
Locality number

Collection Number/References

10,29

$19,23,24,25$

47

25

$2,4,7,19,37,47$

41

$10,11,56$

47

$19,23,25,31,58,61$

19

31

$23,24,25,30,31$

$3,16,17,27$

24,25

19

$2,4,7,12,14,22,31,37$,

$40,44,57,60$

26,27

24

62

$9,39,41$

47

47

63

25

19,21

$2,4,12,19,33,38,59,64$

51

$4,7,15,19,24,27,29,31, \quad A F 4360,4379,4388,4420,4423,4426,4438,6102,6117,6159,23075, A F$ $37,47,57$

24,25

25,27

19

$A F$ \& PR 10559, 17216

$A F$ E PR 13121, 13152, 13163, 13229, 15536, 15604, 15717, 15733 (Flakus et al. 2012, 2013)

$M K 10311$

$A F$ \& PR 15718, 15749

(Nylander 1859)

$A F$ 3691, 4371, 4372, 6157.2, 23075.1, AF \& fQ 19482.2, AF \& PR 1312 $A F \mathcal{E} O P 21301$

$A F$ 24647, $A F$ \& PR 10537.1, 10684, MK 6452, 6544

$A F 23080$

AF $\mathcal{O}$ FS 17895, AF $\mathcal{E} P R$ 13291, 15567, 15736, MK 11985 (Flakus et al. 2013), Stab LB20

$A F$ E PR 13145

$A F$ \& FS 17897

$A F 17842, A F$ \& FS 17879, AF \& PR 15534, 15547, 15610, 15611, 15735, 15755

$A F 4326, A F$ \& $P R 12116,12627,16214,16217$

$A F$ \& PR 15587, 15620, 15753.1 (Flakus et al. 2012)

$A F$ \& $P R 13213$

$A F 3723,4377,6160,11238, A F$ \& $F S$ 17896, 17909, AF \& FQ 19483, AF \& OP 21050, AF \& PR 14194, 14226, MK 6899, 7113, 9997, 12047, 11956a $A F$ \& $P R$ 16096, 16218

$A F$ \& $P R 15618$

Derakshani 25

AF \& OP 20657, 21336, MK 6173

$M K 10326$

MK 10302

Derakshani 39, 53

$A F$ \& $P R 15738$

$A F$ \& $P R$ 13197, 13885,13908

$A F$ 3681, 4357, 4405, 11226, 11237, AF \& $\mathcal{7 O} 18962,20168,20209, A F$ \& PR 13123, 24800, Derakshani 38 AF 23568

E FS 17858, AF \& $7 O$ 19482, AF \& PR 24749, 13251, 15602, 15603 , $15606.1,15619,15626,15629.1,16271.3,17307, M K 7118$

$A F$ E PR 15630, 15720

$A F$ \& $P R$ 15752, 16224

$A F$ \& $P R 13278$ 


\begin{tabular}{|c|c|c|}
\hline Species name & Locality number & Collection Number/References \\
\hline Astrothelium subscoria Flakus \& Aptroot & 16 & $A F$ E PR 12118 \\
\hline A. variolosum (Ach.) Müll. Arg. & $6,7,23$ & $A F$ 6091.1, 6149, 6153.1, AF \& PR 15537 \\
\hline A. variabile Flakus \& Aptroot & 26,31 & $A F \& F S 17866,17883,17934, A F$ \& $P R 16108$ \\
\hline A. versicolor Müll. Arg. & 23,25 & $A F \& P R 15549,15715,15719$ \\
\hline Bathelium boliviense Flakus \& Aptroot & 21,31 & $A F \mathcal{E} F S$ 17921, $A F \mathcal{E} P R 13907$ \\
\hline Bogoriella alata (Groenh. ex Aptroot) Aptroot \& Lücking & 38 & $A F \mathcal{F} \mathcal{F Q} 20182$ \\
\hline B. apposita (Nyl.) Aptroot \& Lücking & 35 & $A F \& \mathcal{F} Q 19188,19230$ \\
\hline B. flavostiolatum Flakus \& Aptroot & 20,31 & $A F \mathcal{E} F S$ 17911, $A F$ E PR 13747 \\
\hline B. madreporiforme (Eschw.) Trevis. ${ }^{\star}$ & 25,50 & AF $\& P R$ 15754, MK 10601 (Flakus et al. 2013) \\
\hline B. mastoideum Afzel. ex Ach.` & 7,23 & $A F$ 6128, $A F$ \& $P R$ 15562, 15563 (Flakus et al. 2013) \\
\hline B. miculiformis (Nyl. ex Müll. Arg.) Aptroot \& Lücking & 50 & $A F 23518.1,23550$ \\
\hline B. mirabile Flakus et al. & 31,42 & $A F \& F S$ 17922, MK 9706 \\
\hline B. modesta (Müll. Arg.) Aptroot \& Lücking & 56 & $A F 24649.1$ \\
\hline B. nonensis (Stirt.) Aptroot \& Lücking & 28,45 & $A F$ \& $P R$ 16419.4, MK 10183 \\
\hline B. pruinosum Flakus et al. & $52,53,60$ & $A F$ 23709, $M K$ 10679a, 12052 \\
\hline B. punctata (Aptroot) Aptroot \& Lücking & $5,10,13,43$ & $A F$ 4648, 11731.1, AF \& OP 22382, AF \& PR 10454 \\
\hline B. subfallens (Müll. Arg.) Aptroot \& Lücking & 29 & $A F \& P R 17284$ \\
\hline Marcelaria purpurina (Nyl.) Aptroot et al. ${ }^{\star}$ & $20,21,23,24,25$ & $\begin{array}{l}\text { AF } \mathcal{E} P R 13720,13881,13887.1,13904,15580,15614,15760 \text { (Aptroot et al. } \\
\text { 2013) }\end{array}$ \\
\hline Mycomicrothelia melanospora (Hepp) D. Hawksw. ${ }^{\star}$ & & (Nylander 1859) \\
\hline Nigrovothelium tropicum (Ach.) Lücking et al. ${ }^{\star}$ & $\begin{array}{l}19,21,24,31,32,33,34 \\
38,49\end{array}$ & $\begin{array}{l}\text { AF 23438, AF \& FS 17887, AF \& FQ 18883, 18933, 19099, 20178, 20183, AF \& } \\
\text { PR 13110, 13112, 13161, 13885.1, 15609.1 (Flakus et al. 2013) }\end{array}$ \\
\hline Novomicrothelia oleosa (Aptroot) Aptroot \& Lücking & 25 & $A F$ \& $P R$ 15763, 15765 \\
\hline Polymeridium albidum (Müll. Arg.) R. C. Harris` & & (Flakus et al. 2013) \\
\hline P. albopruinosum (Makhija \& Patwardhan) Aptroot & 19 & $A F$ E PR 13241 \\
\hline P. catapastrum (Nyl.) R. C. Harris & 24,46 & $A F 23064, A F \& P R 15631$ \\
\hline P. inspersum Aptroot & 7 & $A F 6131$ \\
\hline P. multiforme Aptroot & 24,50 & $A F$ 23493.1, $A F$ E PR 15632 \\
\hline P. quinqueseptatum (Nyl.) R. C. Harris & 36 & $A F, \mathfrak{f} Q \mathcal{E} A W 19279,19305$ \\
\hline P. subcinereum (Nyl.) R. C. Harris` & & (Flakus et al. 2013) \\
\hline P. subvirescens (Leighton) Aptroot & 24 & $A F$ E PR 15623 \\
\hline P. xanthoexcentricum Flakus \& Aptroot & 34 & $A F \mathcal{E} \mathcal{F} Q 18991$ \\
\hline Pseudopyrenula diluta (Fée) Müll. Arg. & $15,33,34,35,48$ & $\begin{array}{l}\text { AF 23358, 23364, 23383, 23389, 11792, AF \& } \mathcal{F Q ~ 1 8 9 3 8 , ~ 1 9 0 5 4 , ~ 1 9 0 7 0 , ~} \\
\text { 19120, 19135, 19185, 19207 }\end{array}$ \\
\hline P. dubia Vain. & $9,18,55$ & $A F 12944,24483, A F \& P R 10227$ \\
\hline P. flavoreagens Aptroot \& M. Cáceres & 19 & $A F \mathcal{E} P R 13185,13254$ \\
\hline
\end{tabular}

$A F$ \& $P R 1324$

P. catapastrum (Nyl.) R. C. Harris

inspersum Aptroot

$A F 6131$

P. quinqueseptatum (Nyl.) R. C. Harris

P. subcinereum (Nyl.) R. C. Harris ${ }^{\star}$

P. subvirescens (Leighton) Aptroot

Pseudopyrenula diluta (Fée) Müll. Arg.

$19120,19135,19185,1920$
$A F 12944,24483, A F \& P R$

AF E PR 13185, 1325 


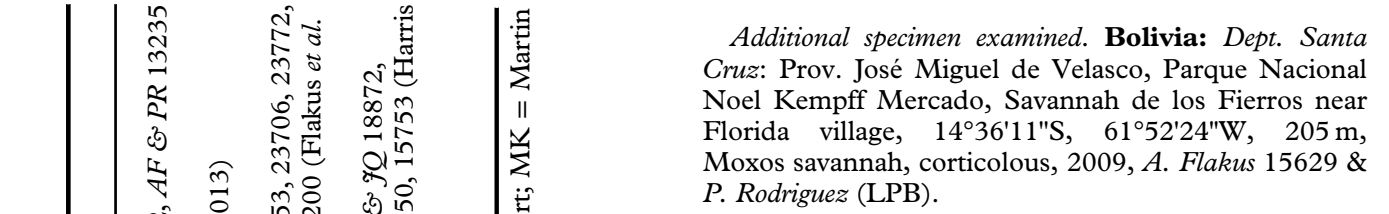

\section{Discussion}

The Amazon Basin, the humid Andes and the semi-arid region of the Gran Chaco in Bolivia belong to the world's most speciesrich areas. Various plant communities, such as lowland Amazon forest, Moxos savannah, Yungas and Tucumano-Boliviano forests, Chaqueño forest, and Chiquitano forest, form a vegetation mosaic which offers a wide range of potential habitats for lichens of the family Trypetheliaceae (Navarro \& Maldonado 2002; Ibisch \& Mérida 2004; Navarro \& Ferreira 2007). We have extensively studied Trypetheliaceae in Bolivia and as a result a total of 75 species are currently known from the country, of which 24 are described here as new to science and 37 are reported for the first time from Bolivia (Table 1). This proves that Bolivia harbours c. $20 \%$ of the c. 400 species of Trypetheliaceae so far recognized worldwide (Aptroot \& Lücking 2016). The number of newly described species in this paper is very high but comparable to the situation in Rondônia (Aptroot \& Cáceres 2016). It should be noted that these are two neighbouring areas. The presence of such a high number of species suggests that Bolivia is one of the centres of speciation of the family, at least of the genera Astrothelium Eschw. and Bathelium Ach.

We are greatly indebted to Rosa I. Meneses Q., the Director of Herbario Nacional de Bolivia, Instituto de Ecología, Universidad Mayor de San Andrés, La Paz, for generous cooperation, several people who were very helpful during the fieldwork, in particular Pamela Rodriguez Flakus (Krakow), Francisco Saavedra, Javier Quisbert and Oscar Plata (La Paz), and Marcin Żamojć (Gdańsk) for linguistic help. This research received support from the National Centre for Research and Development (NCBiR) in Poland under the LIDER Programme for the years 2010-2013 (no. 92/L-1/09), and from the W. Szafer Institute of Botany, Polish Academy of Sciences through its statutory funds. 


\section{REFERENCES}

Aptroot, A. (1991) A monograph of the Pyrenulaceae (excluding Anthracothecium and Pyrenula) and the Requienellaceae, with notes on the Pleomassariaceae, the Trypetheliaceae and Mycomicrothelia (lichenized and non-lichenized Ascomycetes). Bibliotheca Lichenologica 44: 1-178.

Aptroot, A. (2009) Trypetheliaceae. In Flora of Australia, Volume 57, Lichens 5. (P. M. McCarthy, ed.): 534-552. Canberra and Melbourne: ABRS and CSIRO Publishing.

Aptroot, A. \& Cáceres, M. E. S. (2014) A revised species concept in the tropical microlichen genus Polymeridium (Trypetheliaceae) doubles the number of known species, with a world key to species. Nova Hedwigia 98: 1-29.

Aptroot, A. \& Cáceres, M. E. S. (2016) New Trypetheliaceae from the Amazon basin in Rondonia (Brazil), the centre of diversity of the genus Astrothelium. Lichenologist 48: 693-712.

Aptroot, A. \& Lücking, R. (2016) A revisionary synopsis of the Trypetheliaceae (Ascomycota: Trypetheliales). Lichenologist 48: 763-982.

Aptroot, A., Lücking, R., Sipman, H. J. M., Umaña, L. \& Chaves, J. L. (2008) Pyrenocarpous lichens with bitunicate asci: a first assessment of the lichen biodiversity inventory in Costa Rica. Bibliotheca Lichenologica 97: 1-162.

Aptroot, A., Nelsen, M. P. \& Parnmen, S. (2013) Marcelaria, a new genus for the Laurera purpurina group in the Trypetheliaceae (Ascomycota: Dothideomycetes). Glalia 5: 1-14.

Aptroot, A., Mendonça, C. O., Andrade, D. S., Silva, J. R., Martins, S. M. A., Gumboski, E., Fraga Júnior, C. A. V. \& Cáceres, M. E. S. (2016) New Trypetheliaceae from northern and southern Atlantic rainforests in Brazil.. Lichenologist 48: 713-725.

Flakus, A., Etayo, J., Schiefelbein, U., Ahti, T., Jabłońska, A., Oset, M., Kerstin, B., Rodriguez Flakus, P. \& Kukwa, M. (2012) Contribution to the knowledge of the lichen biota of Bolivia. 4. Polish Botanical fournal 57: 427-461.

Flakus, A., Sipman, H. J. M., Bach, K., Rodriguez Flakus, P., Knudsen, K., Ahti, T., Schiefelbein, U., Palice, Z., Jabłońska, A., Oset, M., et al. (2013) Contribution to the knowledge of the lichen biota of Bolivia. 5. Polish Botanical fournal 58: 697-733.
Harris, R. C. (1995) More Florida Lichens. Including the 10\% Tour of the Pyrenolichens. New York: Published by the author.

Hawksworth, D. L. (1985) A redisposition of the species referred to the ascomycete genus Microthelia. Bulletin of the British Museum (Natural History), Botany 14: 43-181.

Ibisch, P. L. \& Mérida, G. (eds) (2004) Biodiversity: the Richness of Bolivia. State of Knowledge and Conservation. Santa Cruz de la Sierra, Bolivia: Editorial FAN.

Josse, C., Navarro, G., Comer, P., Evans, R., Faber-Langendoen, D., Fellows, M., Kittel, G., Menard, S., Pyne, M., Reid, M. et al. (2003) Ecological Systems of Latin America and the Caribbean: a Working Classification of Terrestrial Systems. Arlington, Virginia: NatureServe.

Lücking, R., Rivas Plata, E., Chaves, J. L., Umaña, L. \& Sipman, H. J. M. (2009) How many tropical lichens are there really? Bibliotheca Lichenologica 100: 399-418.

Malme, G. O. A. (1924) Die Flechten der ersten Regnellschen Expedition. 2. Astrotheliaceae, Paratheliaceae und Trypetheliaceae. Arkiv för Botanik 19: 1-34.

Navarro, G. \& Ferreira, W. (2007) Mapa de Vegetación de Bolivia a Escala 1:250.000. Ed. digital. Santa Cruz de la Sierra: The Nature Conservancy (TNC).

Navarro, G. \& Maldonado, M. (2002) Geografía Ecológica de Bolivia: Vegetación y Ambientes Acuáticos. Santa Cruz, Bolivia: Centro de Ecología Difusíon Simón I. Patiño.

Nylander, W. (1859) Lichenes in regionibus exoticis quibusdam vigentes exponit synopticis enumerationibus. Annales des Sciences Naturelles, Botanique 11: 205-264.

Orange, A., James, P. W. \& White, F. J. (2001) Microchemical Methods for the Identification of Lichens. London: British Lichen Society.

Wijayawardene, N. N., Crous, P. W., Kirk, P. M., Hawksworth, D. L., Boonmee, S., Braun, U., Dai, D. Q., D'souza, M. J., Diederich, P., Dissanayake, A. et al. (2014) Naming and outline of Dothideomycetes-2014 including proposals for the protection or suppression of generic names. Fungal Diversity 69: 1-55.

\section{Appendix. List of localities for the corticolous lichens of the family Trypetheliaceae from Bolivia}

1. Dept. Beni, Prov. Ballivian, by Lago Copaiba near Reyes village, $14^{\circ} 17^{\prime} 56^{\prime \prime S}, 67^{\circ} 14^{\prime} 16^{\prime \prime W}, 189 \mathrm{~m}$, lowland Amazon forest surrounded by Moxos savannah, 27 November 2004.

2. Dept. Beni, Prov. Ballivian, near Reyes village, $14^{\circ} 18^{\prime} 10^{\prime \prime} \mathrm{S}, 67^{\circ} 18^{\prime} 49^{\prime \prime} \mathrm{W}, 192 \mathrm{~m}$, Moxos savannah, 29 November 2004.
3. Dept. Beni, Prov. Ballivian, near Río Pircayo, $14^{\circ} 18^{\prime} 56^{\prime \prime S}, 67^{\circ} 26^{\prime} 34^{\prime \prime} \mathrm{W}, 190 \mathrm{~m}$, lowland Amazon forest, 4 December 2004.

4. Dept. Beni, Prov. Ballivian, near Reyes village, $14^{\circ} 18^{\prime} 10^{\prime \prime} \mathrm{S}, 67^{\circ} 18^{\prime} 49^{\prime \prime} \mathrm{W}, 192 \mathrm{~m}$, Moxos savannah, 5 December 2004. 
5. Dept. Santa Cruz, Prov. Caballero, East Cordillera, Siberia region near La Palma village, $17^{\circ} 49^{\prime} 12^{\prime \prime S}$, $64^{\circ} 40^{\prime} 28^{\prime \prime W}, 2582 \mathrm{~m}$, Yungas cloud forest, 13 December 2004.

6. Dept. Pando, Prov. Manuripi, Reserva Nacional de Vida Silvestre Amazónica Manuripi, Bajada colony near Chive village by Río Madre de Dios, $12^{\circ} 24^{\prime} 03^{\prime \prime S}, 68^{\circ} 26^{\prime} 45^{\prime \prime W}, 170 \mathrm{~m}$, lowland Amazon forest, 19 May 2006.

7. Dept. Pando, Prov. Manuripi, Reserva Nacional de Vida Silvestre Amazónica Manuripi, Metale colony near Chive village by Río Madre de Dios, $12^{\circ} 20^{\prime} 38^{\prime \prime} \mathrm{S}, 68^{\circ} 20^{\prime} 40^{\prime \prime} \mathrm{W}, 170 \mathrm{~m}$, lowland Amazon forest, 19 May 2006.

8. Dept. Beni, Prov. Vaca Diez, Riberalta village, Mercado Central, $10^{\circ} 59^{\prime} 49^{\prime \prime} \mathrm{S}, 66^{\circ} 04^{\prime} 28^{\prime \prime} \mathrm{W}, 152 \mathrm{~m}$, city park, 3 June 2006.

9. Dept. Cochabamba, Prov. Carrasco, Parque Nacional Carrasco, near Phaqcha, $20 \mathrm{~km}$ from Monte Punku village, $17^{\circ} 27^{\prime} 13^{\prime \prime} \mathrm{S}, 65^{\circ} 16^{\prime} 44^{\prime \prime} \mathrm{W}, 2850 \mathrm{~m}$, Yungas cloud forest, 20 July 2008.

10. Dept. Cochabamba, Prov. Carrasco, Parque Nacional Carrasco, near Sehuencas village, $17^{\circ} 30^{\prime} 12^{\prime \prime S}$, $65^{\circ} 16^{\prime} 30^{\prime \prime} \mathrm{W}, 2220 \mathrm{~m}$, Yungas cloud forest, 21 July 2008.

11. Dept. Cochabamba, Prov. Carrasco, Parque Nacional Carrasco, between Sehuencas and Monte Punku villages, steep slopes of the valley, $17^{\circ} 30^{\prime} \mathrm{S}$, $65^{\circ} 16^{\prime} \mathrm{W}, 2200 \mathrm{~m}$, Yungas cloud forest, $22 \mathrm{July}$ 2008.

12. Dept. La Paz, Prov. Iturralde, near San Pedro village, $13^{\circ} 43^{\prime} 59^{\prime \prime} \mathrm{S}, 68^{\circ} 00^{\prime} 38^{\prime \prime} \mathrm{W}, 250 \mathrm{~m}$, Moxos savannah, 28 July 2008.

13. Dept. La Paz, Prov. Iturralde, near Tumupasa village, $14^{\circ} 08^{\prime} 51^{\prime \prime} \mathrm{S}, 67^{\circ} 53^{\prime} 34^{\prime \prime} \mathrm{W}, 350 \mathrm{~m}$, preandean Amazon forest, 31 July 2008.

14. Dept. Beni, Prov. Ballivian, Palmar village, $14^{\circ} 58^{\prime} 56^{\prime \prime} \mathrm{S}, 67^{\circ} 05^{\prime} 16^{\prime \prime} \mathrm{W}, 250 \mathrm{~m}$, near the road, 2 August 2008.

15. Dept. La Paz, Prov. Nor Yungas, near Pacallo village, $16^{\circ} 12^{\prime} 10^{\prime \prime} \mathrm{S}, 67^{\circ} 50^{\prime} 39^{\prime \prime} \mathrm{W}, 1360 \mathrm{~m}$, Yungas montane forest, 3 August 2008.

16. Dept. Beni, Prov. Itenez, Puerto Feliz colony by Río Blanco, $13^{\circ} 09^{\prime} 23^{\prime \prime S}, 63^{\circ} 43^{\prime} 24^{\prime \prime} \mathrm{W}, 137 \mathrm{~m}$, lowland Amazon forest, 16 August 2008.

17. Dept. Beni, Prov. Itenez, Cerro de Oricore by Río San Martín, $13^{\circ} 19^{\prime} 55^{\prime \prime S}, 63^{\circ} 30^{\prime} 37^{\prime \prime W}, 240 \mathrm{~m}$, dry forest overgrowing granitic hill, inselberg, 19 August 2008.

18. Dept. Cochabamba, Prov. Chapare, near Incachaca, $17^{\circ} 12^{\prime} 54^{\prime \prime} \mathrm{S}, 65^{\circ} 49^{\prime} 30^{\prime \prime} \mathrm{W}, 2028 \mathrm{~m}$, Yungas cloud forest near road, 7 July 2009.

19. Dept. Santa Cruz, Prov. Guarayos, Reserva Natural de Vida Silvestre Ríos Blanco y Negro, Virgen de Pilar near Chonta village, $15^{\circ} 38^{\prime} 54^{\prime \prime S}, 62^{\circ} 57^{\prime} 37^{\prime \prime} \mathrm{W}$, $229 \mathrm{~m}$, lowland Amazon forest, 22 July 2009.

20. Dept. Santa Cruz, Prov. Guarayos, Reserva Natural de Vida Silvestre Ríos Blanco y Negro, Plan de Manejo AISU, 15 ${ }^{\circ} 09^{\prime} 13^{\prime \prime S}, 62^{\circ} 47^{\prime} 57^{\prime \prime W}$, $240 \mathrm{~m}$, lowland Amazon forest, 24 July 2009.

21. Dept. Santa Cruz, Prov. Guarayos, Reserva Natural de Vida Silvestre Ríos Blanco y Negro,
Plan de Manejo AISU, $15^{\circ} 01^{\prime} 58^{\prime \prime} \mathrm{S}, 62^{\circ} 46^{\prime} 36^{\prime \prime W}$ $242 \mathrm{~m}$, lowland Amazon forest, 24 July 2009.

22. Dept. Santa Cruz, Prov. Guarayos, Reserva Natural de Vida Silvestre Ríos Blanco y Negro, Plan de Manejo AISU, $15^{\circ} 01^{\prime} 49^{\prime \prime} \mathrm{S}, 62^{\circ} 46^{\prime} 36^{\prime \prime} \mathrm{W}, 236 \mathrm{~m}$, lowland Amazon forest, 25 July 2009.

23. Dept. Santa Cruz, Prov. J. M. de Velasco, Parque Nacional Noel Kempff Mercado, Camino los Fierros near Florida village, $14^{\circ} 32^{\prime} 25^{\prime \prime} \mathrm{S}, 61^{\circ} 03^{\prime} 13^{\prime \prime} \mathrm{W}, 215 \mathrm{~m}$, lowland Amazon forest, 14 December 2009.

24. Dept. Santa Cruz, Prov. J. M. de Velasco, Parque Nacional Noel Kempff Mercado, Savana de los Fierros near Florida village, $14^{\circ} 36^{\prime} 11^{\prime \prime} \mathrm{S}, 61^{\circ} 52^{\prime} 24^{\prime \prime W}$, $205 \mathrm{~m}$, Moxos savannah, 15 December 2009.

25. Dept. Santa Cruz, Prov. J. M. de Velasco, Parque Nacional Noel Kempff Mercado, near Florida village, $14^{\circ} 35^{\prime} 50^{\prime \prime} \mathrm{S}, 61^{\circ} 50^{\prime} 46^{\prime \prime} \mathrm{W}, 215 \mathrm{~m}$, cerrado, 15 December 2009.

26. Dept. Santa Cruz, Prov. J. M. de Velasco, Sendero de goma near Florida village, $14^{\circ} 37^{\prime} 48^{\prime \prime} \mathrm{S}, 61^{\circ} 12^{\prime} 02^{\prime \prime} \mathrm{W}$, $170 \mathrm{~m}$, lowland Amazon secondary forest, 16 December 2009.

27. Dept. Santa Cruz, Prov. J. M. de Velasco, Hacienda Chirapa near Florida village, $14^{\circ} 33^{\prime} 22^{\prime \prime} \mathrm{S}, 61^{\circ}$ $16^{\prime} 03^{\prime \prime} \mathrm{W}, 200 \mathrm{~m}$, lowland Amazon forest, 16 December 2009.

28. Dept. La Paz, Prov. Nor Yungas, Coroico village, $16^{\circ} 11^{\prime} 10^{\prime \prime} \mathrm{S}, 67^{\circ} 43^{\prime} 16^{\prime \prime} \mathrm{W}, 1550 \mathrm{~m}$, Yungas montane forest, 6 June 2010.

29. Dept. La Paz, Prov. Nor Yungas, Parque Nacional y Área natural de Manejo Integrado Cotapata, near Urpuma colony, $16^{\circ} 13^{\prime} 20^{\prime \prime S}, 67^{\circ} 52^{\prime} 34^{\prime \prime W}, 1989 \mathrm{~m}$, Yungas montane forest, 30 June 2010.

30. Dept. Beni, Prov. Yacuma, Reserva de la Biosfera Estación Biológica del Beni, near la Estación Biológica, $14^{\circ} 51^{\prime} 32^{\prime \prime S}, 66^{\circ} 19^{\prime} 55^{\prime \prime} \mathrm{W}, 179 \mathrm{~m}$, island of lowland Amazon forest among Moxos savannah, 6 November 2010.

31. Dept. Beni, Prov. Yacuma, Reserva de la Biosfera Estación Biológica del Beni, near la Estación Biológica, $14^{\circ} 51^{\prime} 07^{\prime \prime} \mathrm{S}, 66^{\circ} 20^{\prime} 23^{\prime \prime} \mathrm{W}, 175 \mathrm{~m}$, island of lowland Amazon forest among Moxos savannah, 6 November 2010.

32. Dept. Santa Cruz, Prov. Cordillera, Parque Nacional y Área Natural de Manejo Integrado Kaa-Iya del Gran Chaco, Bañados del Izozog, near Río Parapeti, $18^{\circ} 28^{\prime} 40^{\prime \prime} \mathrm{S}, 62^{\circ} 05^{\prime} 03^{\prime \prime} \mathrm{W}, 296 \mathrm{~m}$, Ribereño forest, 2 December 2010.

33. Dept. Santa Cruz, Prov. Cordillera, Parque Nacional y Área Natural de Manejo Integrado Kaa-Iya del Gran Chaco, gasoducto Bolivia-Brasil KP 164, $60 \mathrm{~km}$ from Tucavaca colony, $18^{\circ} 27^{\prime} 29^{\prime \prime} \mathrm{S}, 61^{\circ} 23^{\prime} 01^{\prime \prime} \mathrm{W}$, 292 m, Chaqueño forest, 3 December 2010.

34. Dept. Santa Cruz, Prov. Cordillera, Parque Nacional y Área Natural de Manejo Integrado Kaa-Iya del Gran Chaco, gasoducto Bolivia-Brasil, near Tucavaca colony, $18^{\circ} 30^{\prime} 19^{\prime \prime} \mathrm{S}, 60^{\circ} 57^{\prime} 14^{\prime \prime} \mathrm{W}, 278 \mathrm{~m}$, Chiquitano forest, 4 December 2010.

35. Dept. Santa Cruz, Prov. Cordillera, Parque Nacional y Área Natural de Manejo Integrado Kaa-Iya del Gran Chaco, gasoducto Bolivia-Brasil, between Tucavaca colony and National Park border, 18 $31^{\prime} 40^{\prime \prime S}$, 
$60^{\circ} 41^{\prime 26} \mathrm{WW}, 314 \mathrm{~m}$, Chiquitano forest, 4 December 2010.

36. Dept. Santa Cruz, Prov. Chiquitos, near Santa Cruz de la Vieja, el Mirador a San José de Chiquitos, $17^{\circ} 52^{\prime} 21^{\prime \prime} \mathrm{S}, 60^{\circ} 45^{\prime} 41^{\prime \prime W}, 501 \mathrm{~m}$, cerrado, 5 December 2010.

37. Dept. Cochabamba, Prov. Chapare, near Bulo Bulo village, near Río Chimore, $16^{\circ} 58^{\prime} 19^{\prime \prime} S$, $65^{\circ} 21^{\prime} 11^{\prime \prime} \mathrm{W}, 283 \mathrm{~m}$, lowland Amazon forest, 9 December 2010.

38. Dept. Santa Cruz, Prov. Cordillera, Parque Nacional y Área Natural de Manejo Integrado Kaa-Iya del Gran Chaco, Charrata village near campamento de los guardaparques, $18^{\circ} 28^{\prime} 05^{\prime \prime} \mathrm{S}, \quad 62^{\circ} 05^{\prime} 43^{\prime \prime} \mathrm{W}$, $307 \mathrm{~m}$, Chaqueño forest, 2 December 2010.

39. Dept. La Paz, Prov. Larecaja, near Achiquiri village, $18 \mathrm{~km}$ from Mapiri on the road to Apolo, $15^{\circ} 13^{\prime} 31^{\prime \prime S}, 68^{\circ} 13^{\prime} 49^{\prime \prime} \mathrm{W}, 1071 \mathrm{~m}$, Sub-Andean secondary Amazon forest, 16 May 2011.

40. Dept. La Paz, Prov. Saavedra, $28 \mathrm{~km}$ from Charazani village, on the road Charazani-Apolo, $15^{\circ} 12^{\prime} 43^{\prime \prime} \mathrm{S}, 68^{\circ} 47^{\prime} 25^{\prime \prime} \mathrm{W}, 1650 \mathrm{~m}$, Yungas montane forest, open area with boulders, 18 May 2011.

41. Dept. La Paz, Prov. Nor Yungas, Parque Nacional y Área natural de Manejo Integrado Cotapata, Santa Catalina village, above Tunkini, $16^{\circ} 11^{\prime} 12^{\prime \prime} S$, $67^{\circ} 52^{\prime} 07^{\prime \prime W}$, c. $1600 \mathrm{~m}$, Yungas montane forest, 22 May 2011.

42. Dept. Santa Cruz, Prov. Ichilo, Parque Nacional y Área Natural de Manejo Integrado Ámboro, campamento Macuñucu, $17^{\circ} 43^{\prime} 38^{\prime \prime S}, 63^{\circ} 35^{\prime} 37^{\prime \prime W}$, $461 \mathrm{~m}$, lowland Amazon forest, 6 June 2011.

43. Dept. Santa Cruz, Prov. Florida, Parque Nacional y Área Natural de Manejo Integrado Ámboro, above la Yunga village, senda Los Helechos, $18^{\circ} 03^{\prime} 30^{\prime \prime S}$, $63^{\circ} 54^{\prime} 36^{\prime \prime W}, 2330 \mathrm{~m}$, Yungas cloud forest, 7 June 2011.

44. Dept. Santa Cruz, Prov. Andrés Ibáñez, Parque Nacional y Área Natural de Manejo Integrado Ámboro, on the road to San Mateo de Toresilla village, carretera antigua Cochabamba-Comarapa, $17^{\circ} 48^{\prime} 11^{\prime \prime S}, 64^{\circ} 39^{\prime} 28^{\prime \prime} \mathrm{W}, 2250 \mathrm{~m}$, Yungas cloud forest, 9 June 2011.

45. Dept. La Paz, Prov. Franz Tamayo, between Apolo and Mapiri villages, $14^{\circ} 41^{\prime} 50^{\prime \prime} \mathrm{S}, 68^{\circ} 25^{\prime} 07^{\prime \prime} \mathrm{W}$, $1510 \mathrm{~m}$, Moxos savannah with scattered trees, 22 November 2011.

46. Dept. La Paz, Prov. Franz Tamayo, between Apolo and Mapiri villages, $13 \mathrm{~km}$ from Apolo, $14^{\circ} 50^{\prime} 51^{\prime \prime} \mathrm{S}$, $68^{\circ} 21^{\prime} 38^{\prime \prime} \mathrm{W}, 1490 \mathrm{~m}$, Moxos savannah with scattered trees, shrubs along the streams, 23 November 2011.

47. Dept. La Paz, Prov. Franz Tamayo, between Apolo and Mapiri villages, $15^{\circ} 01^{\prime} 50^{\prime \prime} \mathrm{S}$, $68^{\circ} 18^{\prime} 33^{\prime \prime W}, 1120 \mathrm{~m}$, Sub-Andean Amazon forest, 23 November 2011.

48. Dept. Santa Cruz, Prov. Cordillera, Parque Nacional y Área Natural de Manejo Integrado Kaa-Iya del Gran Chaco, Curichi Vibora near Tucavaca colony, $18^{\circ} 27^{\prime} 29^{\prime \prime} \mathrm{S}, 61^{\circ} 23^{\prime} 01^{\prime \prime} \mathrm{W}, 320 \mathrm{~m}$, Chaqueño forest, 2 December 2011.
49. Dept. Santa Cruz, Prov. Cordillera, $350 \mathrm{~km}$ on the road from Tucavaca to Roboré, $18^{\circ} 37^{\prime} 56^{\prime \prime} \mathrm{S}$, $59^{\circ} 36^{\prime} 50^{\prime \prime} \mathrm{W}, \quad 370 \mathrm{~m}$, transition ChiquitanoChaqueño forest, 4 December 2011.

50. Dept. Santa Cruz, Prov. Cordillera, between Tucavaca and Roboré, $18^{\circ} 36^{\prime} 11^{\prime \prime} \mathrm{S}, 59^{\circ} 53^{\prime} 06^{\prime \prime} \mathrm{W}$, $320 \mathrm{~m}$, transition Chiquitano-Chaqueño forest, 4 December 2011.

51. Dept. Santa Cruz, Prov. Cordillera, Parque Nacional y Área Natural de Manejo Integrado Kaa-Iya del Gran Chaco, near Peto Blanco, park guard's station, $18^{\circ} 56^{\prime} 26^{\prime \prime} \mathrm{S}, 60^{\circ} 22^{\prime} 39^{\prime \prime} \mathrm{W}, 340 \mathrm{~m}$, Chiquitano forest, 5 December 2011.

52. Dept. Santa Cruz, Prov. Cordillera, Parque Nacional y Área Natural de Manejo Integrado Kaa-Iya del Gran Chaco, near Peto Blanco, park guard's station, $18^{\circ} 51^{\prime} 36^{\prime \prime} \mathrm{S}, 60^{\circ} 18^{\prime} 00^{\prime \prime} \mathrm{W}, 310 \mathrm{~m}$, transition Chiquitano-Chaqueño forest, 5 December 2011.

53. Dept. Santa Cruz, Prov. Cordillera, near Peto Blanco, park guard's station, $18^{\circ} 48^{\prime} 25^{\prime \prime} \mathrm{S}$, $60^{\circ} 14^{\prime} 54^{\prime \prime} \mathrm{W}, \quad 330 \mathrm{~m}$, transition ChiquitanoChaqueño forest, 6 December 2011.

54. Dept. Tarija, Prov. O'Connor, $24 \mathrm{~km}$ from Entre Ríos, near Soledad, 2139'45"S, 6407'29"W, 1700 m, Tucumano-Boliviano montane forest, 11 August 2012.

55. Dept. Santa Cruz, Prov. Caballero, El Camino de Orquideas, $17^{\circ} 49^{\prime} 20^{\prime \prime S}, 64^{\circ} 42^{\prime} 31^{\prime \prime W}, 2340 \mathrm{~m}$, Yungas cloud forest, 17 August 2012.

56. Dept. Cochabamba, Prov. Carrasco, Parque Nacional Carrasco, near Sehuencas, $17^{\circ} 29^{\prime} 48^{\prime \prime} S$, $65^{\circ} 16^{\prime} 22^{\prime \prime W}, 2250 \mathrm{~m}$, vegetation with Alnus sp. along the river near Yungas cloud forest, 18 August 2012.

57. Dept. Beni, Prov. Marbán, near road from Camiaco to San Lorenzo, $15^{\circ} 14^{\prime} 49^{\prime \prime} \mathrm{S}, 64^{\circ} 49^{\prime} 11^{\prime \prime} \mathrm{W}, 160 \mathrm{~m}$, lowland Amazon forest surrounded by Moxos savannah, 30 August 2012

58. Dept. Beni, Prov. Cercado, Casa del Tigre near Chuchini, 14 $43^{\prime} 17^{\prime \prime S}, 64^{\circ} 56^{\prime} 53^{\prime \prime W}, 160 \mathrm{~m}$, lowland Amazon forest, 31 August 2012.

59. Dept. Beni, Prov. Mamoré, near La Esperanza, 135'ㄴ' 6 "S, 6459'46"W, $140 \mathrm{~m}$, Moxos savannah near lake, 1 September 2012.

60. Dept. Beni, Prov. General José Ballivián Segurola, north of San Borja, $14^{\circ} 46^{\prime} 07^{\prime \prime S}, 66^{\circ} 46^{\prime} 51^{\prime \prime W}$, $190 \mathrm{~m}$, lowland Amazon forest surrounded by Moxos savannah, 3 September 2012.

61. Dept. Beni, Prov. Yacuma, La Trapiche, E.B. Beni, E of San Borja $100 \mathrm{~m}, 20$ October 1988.

62. Dept. Beni, Prov. Sud Yungas, Alto Beni, Colonia Colorada, 1999.

63. Dept. La Paz, Prov. Sud Yungas, Alto Beni, Nueva Israel, $15^{\circ} 34^{\prime} 46 \cdot 2^{\prime \prime} \mathrm{S}, 67^{\circ} 15^{\prime} 54 \cdot 6^{\prime \prime} \mathrm{W}, 540 \mathrm{~m}, 25$ June 1999.

64. Dept. La Paz, Prov. Sud Yungas, Alto Beni, Sapecho, $405 \mathrm{~m}, 15^{\circ} 30 \cdot 79^{\prime} \mathrm{S}, 67^{\circ} 30 \cdot 79^{\prime} \mathrm{W}, 22$ June 1999.

65. Dept. Beni, Prov. Cercado, Trinidad, Missiones Guarauos, 250 m, September 1926. 